\title{
Comparative Analysis of Urban Development Trends of Beijing and Karachi Metropolitan Areas
}

\author{
Muhammad Yousif Mangi ${ }^{1,2, * \mathbb{C}}$, Zhang Yue ${ }^{1, *}$, Saima Kalwar ${ }^{2}$ and Zulfiqar Ali Lashari ${ }^{2}$ \\ 1 Department of Urban Planning, School of Architecture, Tsinghua University, Beijing 100084, China \\ 2 Department of City and Regional Planning, Mehran University of Engineering and Technology, \\ Jamshoro 76062, Pakistan; saimakalwar22@gmail.com (S.K.); zulfiqarlashari5@gmail.com (Z.A.L.) \\ * Correspondence: yousif.mangi@faculty.muet.edu.pk (M.Y.M.); yuezhang@tsinghua.edu.cn (Z.Y.)
}

Received: 21 November 2019; Accepted: 2 January 2020; Published: 7 January 2020

\begin{abstract}
Urban sustainability has become a significant challenge globally due to rapidly growing urbanization and industrialization. Hence, this study was conducted to examine the existing urban development trends of metropolitan cities (i.e., Beijing and Karachi) of China and Pakistan in the context of urban sustainability. The development progress in both cities was examined through urban sustainability indices individually and compared with each other. An index system considering 36 indicators was developed based on social, economic, and environmental aspects. The six years (2012-2017) of data used in this study, were obtained from various governmental websites. Furthermore, the Urban Sustainability Index (USI) was evaluated using the statistical standard equal-weighted method. Results revealed that Beijing's developmental progress is much better than Karachi in terms of socio-economic and environmental development, but there is still a need for improvement. While Karachi faces problems in all three sectors, each indicator of these sectors requires considerable improvement for attaining the top level of the Urban Sustainability Index. However, this study recommends that much attention is needed in the case of Karachi city, whereas Beijing also needs quality advancement in urban development.
\end{abstract}

Keywords: urbanization; urban sustainability; urban development; metropolitan; socio-economic; environmental; Beijing; Karachi

\section{Introduction}

Urbanization is growing at an alarming rate in recent decades globally, and may reach $70 \%$ by the end of 2050 [1-3]. Every day thousands of people migrate towards cities for better living [4,5]. The migration of people from rural to urban areas is widespread [6-8]. As a result, tremendous socio-economic and environmental impacts are rising consistently, as witnessed by the Department of Economic and Social Affairs and Population Funds of the United Nations [2,9].

Meanwhile, the world is transforming itself not only by rapid increases in urban populations, but also in the physical growth of cities [2], leading to higher population densities, abundant built-up structures, large impervious surfaces, altered climatic and hydrological conditions, modified ecosystem functions and services, and so on $[10,11]$. Resultantly, cities face many severe problems including improper delivery of services to the public; traffic congestion; inadequate housing, education, and health; unemployment [1,3,12,13]; slums; crime; shortages of clean water and energy; environmental deterioration [14-17]; municipal solid waste management; and so on [18]. All these problems affect cities' services and quality of urban life $[19,20]$.

China has been experiencing the urbanization and expansion of cities since 1978 [21-23]. Today, urban areas bear a major proportion (59.2\%) of the total population of China [24], which is expected to grow up to $70 \%$ by $2030[25,26]$. Mainly, China's urbanization has increased through market 
reforms and globalization [26]. Thus, the growth and structural changes in socio-economic and spatial conditions of cities has occurred dramatically [26-28]. Cities face various problems including social, environmental, and governance issues [29] such as air pollution, water contamination and scarcity, biodiversity degradation [22,29-32], loss of arable land [31], energy shortages [22], and unbalanced development of infrastructure [26], etc. All these problems are restricting the sustainable development of cities in China [22]. Beijing metropolitan city is one of them.

Pakistan's urbanization and growth of cities have been taking place since 1947, after independence. However, it has been rapidly growing since 1971 [33,34]. At present, urban areas have accommodated $36.4 \%$ of the country's total population [35], which may increase up to $50 \%$ by 2025 [1,35,36]. Most of the urbanization has risen due to the 1947 sub-continent partition, war on terrorism, and rural-urban migration [37,38]. Hence, Pakistan's cities, specifically metropolitan Karachi, have been facing immense challenges regarding socio-economic and environmental circumstances [39], i.e., informal settlements, improper basic facilities, lack of clean water, inadequate sanitation and solid waste management facilities, environmental pollutions, inconvenient public transport, stagnation of economic activities, poor governance, and so on [8,40-43].

The aforementioned problems of metropolitan cities (i.e., Beijing and Karachi) of China and Pakistan are the main obstacles for sustainable development where planning and monitoring are not implemented appropriately [44-46]. Thus, the field of science and policy should come forward and must take an important step to make urban centers sustainable [20].

The term sustainability has been considered as a dynamic and multidimensional process by which different development components at local, regional, and international levels are taken into observation, for instance; the quality balance of ecology and built environments, economic development, population well-being, and so on [47-49]. Sustainability is broadly recognized with three aspects; namely social, economic, and environmental; which are also known as a triple bottom line [50-52]. As for environmental sustainability concerns, decisions are made for the preservation of the natural environment. Economic sustainability aims to use resources efficiently and to make them reliable for achieving long-term benefits. Likewise, social sustainability supports the present and future generations for creating a local environment that is more livable and healthier [53]. Balance among all three pillars leads to the sustainable development of cities. Urban structures improve socio-economically without compromising environmental dimensions, which attain a balance between people and natural resources [54,55]. Additionally, sustainability indicators assist in developing a mechanism to evaluate the level of sustainability within cities $[51,56]$. These indicators represent information about existing conditions and sustainability performances based on urban areas, which can be productive for the management of public resources in the future $[48,57]$.

The Urban Sustainability Index (USI) is a helpful tool in determining a city's development progress sustainably and directs metropolitan managers in developing conditions that would be conducive to sustainability [58-60]. For evaluating the sustainability and criteria for indicators selection, several studies have been carried out internationally. For example, Zinatizadeh et al. [61] designed the Urban Sustainability Index based on 44 indicators that consider social, economic, and environmental aspects, and evaluated different urban areas' developmental progress in Kermanshah city, Iran. Urban sustainability indicators were measured using an improved full permutation polygon synthetic (IFPPSI) technique. Kwatra et al. [62] identified the social, economic, and environmental development progress of various urban areas of India. Nineteen indicators were selected based on their significance and the availability of periodic data. Relationships between all 19 indicators representing different parameters were assessed using correlation analysis. The Z-score statistical equation was then applied to normalize the values of parameters and calculate the Urban Sustainability Index of these areas. Lu et al. [63] assessed the sustainability of 15 common resource-based urban areas in northeast China by adopting 22 indicators. These indicators were grouped into social, economic, and environmental subsystems. The authors determined and ranked the sustainability of these 15 cities by employing the Technique for Order Preference by Similarity to Ideal Solution method. Also, Huang et al. [64] examined the 
megacities' sustainability index in China. Sustainable development indicators were assessed based on their characteristics under Genuine Progress Indicator (GPI), City Development Index (CDI), Environmental Performance Index (EPI), Human Development Index (HDI), Ecological Footprint (EF), Bio-capacity (BC), Gini-coefficient, and Income ratio of urban-rural areas. Gonzalez-Garcia et al. [65] worked on 26 Spanish cities, determining socio-economic and environmental sustainability. In their research, 31 indicators were undertaken. An integrated multi-criteria approach concerning Material Flow Analysis (MFA), Life Cycle Assessment (LCA), and Data Envelopment Analysis (DEA) were used to analyze the Urban Sustainability Index. However, the sustainability indicators measuring techniques adopted in various studies are more complex. They consume a lot of time during the evaluation of time series data. The mathematical calculation process is arduous for the general public to understand [66]. Therefore, the standard statistical equal-weighted $[20,66]$ method was adopted in this study. It is a practical approach, transforming the indicators' data values into normalized values, then adjusting them to between 0 and 1 to weight the indicators. A value closer to 1 is considered as better sustainability, whereas if the value falls closer to 0 , it is counted as weak sustainability $[20,58]$. Most importantly, the mathematical calculations can efficiently perform within a minimum given time frame.

Moreover, sustainability indicators play a vital role in building basic knowledge and exhibiting the rational image of cities' development [56,67]. Sustainability indicators do not only pay attention to environmental pressure, but also point out complementary dispositions between socio-economic and ecological factors $[19,68]$. These indicators assist decision makers by providing useful information for addressing essential urban development issues and involving the political decision-making process at the different territorial levels to both promote and balance socio-economic and environment systems [69-71]. In this way, it could be possible to measure the sustainability of urban development by integrating urban sustainability indicators into the index, which presents an optimal and concise synopsis of sustainability. The index system is a composite of all indicators, dimensions, and variables used to examine urban sustainability $[65,72]$. Hence, both the index and the indicators are helpful for both scientists and development authorities as imparting tools with which the sustainability of urban development can be measured appropriately [58,73].

In the end, based on reviewed literature and authors' knowledge, various studies were conducted internationally using urban sustainability indicators by adopting different techniques to measure the socio-economic and environmental development trends of urban areas. However, this was a unique study, which was conducted as a comparative study of metropolitan-scale urban areas (i.e., Beijing and Karachi) of China and Pakistan. Both Beijing and Karachi metropolitan cities' current socio-economic and environment developmental progress were examined through the Urban Sustainability Index, both individually and in comparison to each other. The urban sustainability indicators were measured using the statistical standard equal-weighted method. This study was undertaken, in particular, to observe the existing development state of the Karachi metropolitan area, Pakistan, as Karachi city has undergone the worst situation of socio-economic and environmental development. This study may assist policymakers, urban managers, and other officials serving in metropolitan cities to address urban development issues, and could suggest possible ways to improve the quality of balanced urban development at the metropolitan level for achieving sustainable development goals.

\section{Urban Development Trends of China and Pakistan}

At present, the rapid process of urbanization is mainly affecting in the eastern and southern countries of Asia [33,39,74], including China and Pakistan [75]. It is also happening in other regions of the Asian continent [39]. China's urbanization is mostly attributed to the transformation of traditional rural societies into urban culture [76,77]. Modernization in an increasing number of cities has caught the attention of various researchers and administrative authorities, interested in studying the challenges of urbanization [46]. The trend of emerging cities is not new in China. Early cities were developed mainly on the riverside, where water was easily available for irrigating agricultural fields to achieve 
production. Twenty-six more cities were developed in the period of the Shang Dynasty (1600 B.C.-1046 B.C.) along the Weihe River [46]. Furthermore, China experienced important changes in the urban system during the Opium War between 1840 and 1949 A.D. The western world was holding much influence on Chinese political and economic activities, which caused the relocation of industries near large cities, particularly coastal and riverside areas. These cities grew much faster than other cities located across China. At this time, $76.2 \%$ of China's cities existed in coastal areas. Shanghai was the only city that kept almost one-third of the urban population of China, modern industrial-based capital, workforce, and the country's outputs. Subsequently, about 10.6\% of urbanization was observed in 1949 during the independence of the People's Republic of China [46]. For the first time in history, China experienced unprecedented and rapid urbanization in 1978 [21-23]. It was counted as the world's largest flow of population from rural to urban areas in history [22,26]. The urbanization proportion went up from $17.92 \%$ to $49.95 \%$ between 1978 and 2010, with about $1 \%$ average growth rate $[22,25,78]$, and was noted to be more than $56 \%$ in 2015 [31,32,79]. Presently, 59.2\% of the total population of China is living in urban areas [24]. This number is expected to reach $70 \%$ by 2030 [25]. About more than one billion people may live in urban areas by this time [21,80], and this percentage will grow further, up to $80 \%$ at the end of 2050 [24], as pointed out in Figures 1 and 2 . The urbanization trend in China is mainly based on three periods. The rapid declination phase (1960-1978), stable ascension phase (1979-1995), and the rapid development phase after 1995, which have largely benefited stakeholders [29,31,81]. Most of the urbanization has increased significantly in China by adopting market reforms and globalization for the past three decades [26]. As a result, growth and structural changes in socio-economic and spatial conditions have been happening dramatically [26-28]. Rapid economic development and urbanization have caused the growth of urban areas consistently. Approximately $78.5 \%$ of developed land areas expanded during 2003-2013 in China, which was much faster than the growth of the urban population $(46 \%)$ of China. Almost $30 \%$ of forests, grassland, and agricultural fields were converted for urban land use between 1979 and 2010 [23]. The number of cities has also increased, from 193 to 657 between 1978 and 2011 [30]. Thus, China has attained the title as the largest transforming urban society in the world $[30,79,82]$.

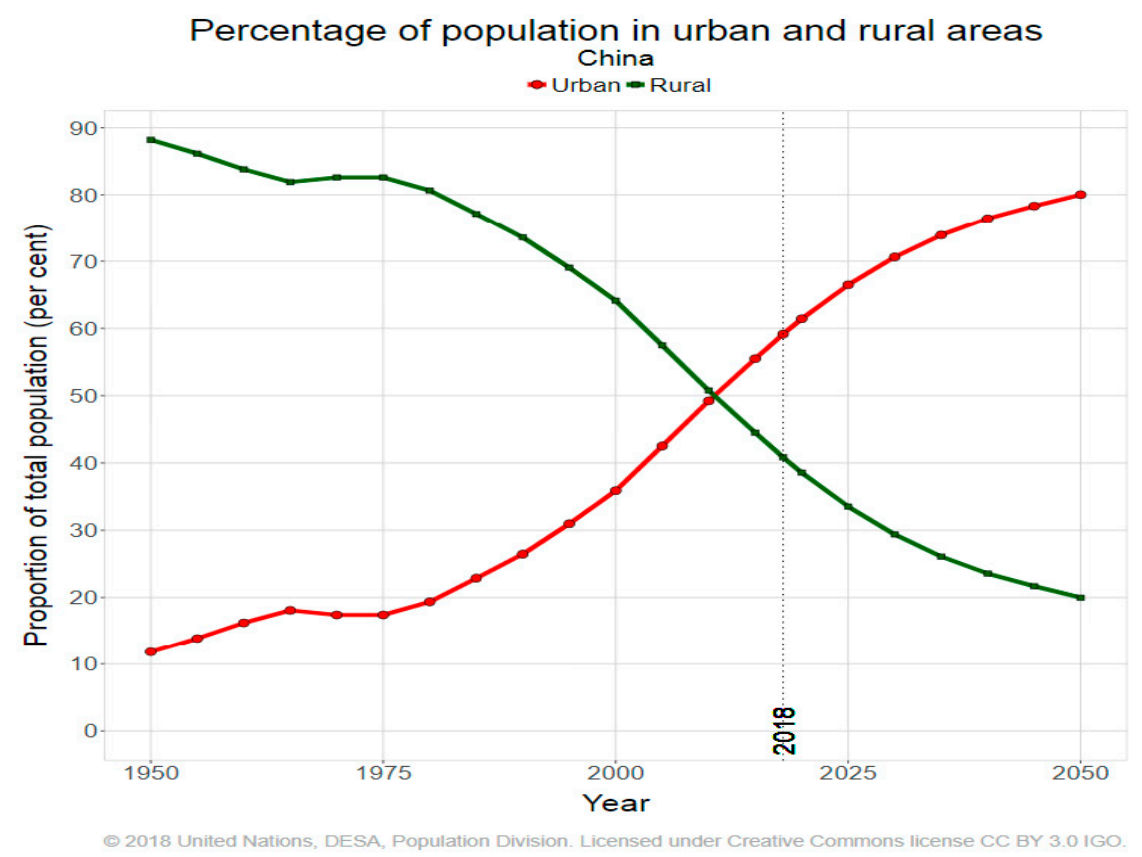

Figure 1. Urban and rural population proportion of China, 1955-2050 [24]. 


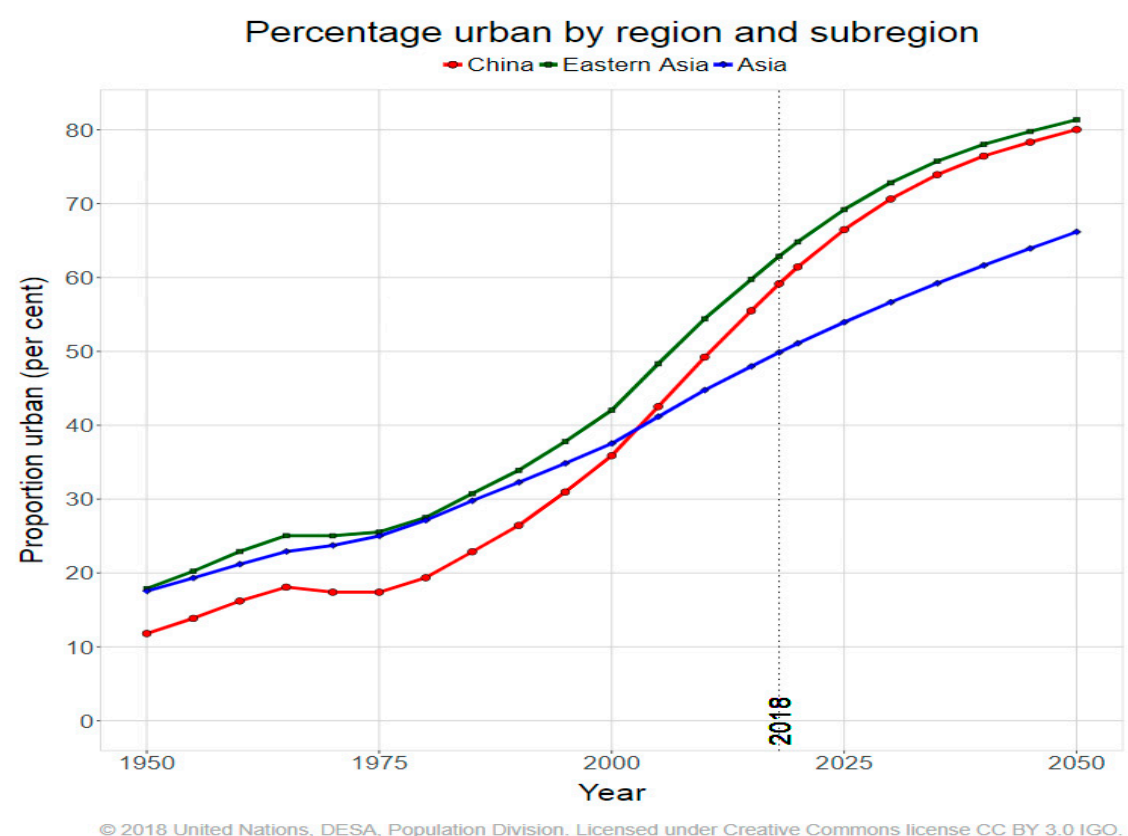

Figure 2. China and other Asian regions' urban population proportion, 1950-2050 [24].

Apart from the urban settlement of China, according to the United Nations in 1990, there were 32 cities with one to five million people, 37 cities with 500,000 to one million inhabitants, 65 urban areas with 300,000 to 500,000 dwellers, and only two cities had five to 10 million residents. Today, there are six metropolitan cities in China, bearing more than 10 million people, 13 urban settlements with a population of five to 10 million, 105 urban areas with one to five million dwellers, 160 cities with 500,000 to one million residents, and 140 cities under a 300,000 to 500,000 person population, as shown in Figures 3 and 4. This number will change in the future, by 2030 [24].

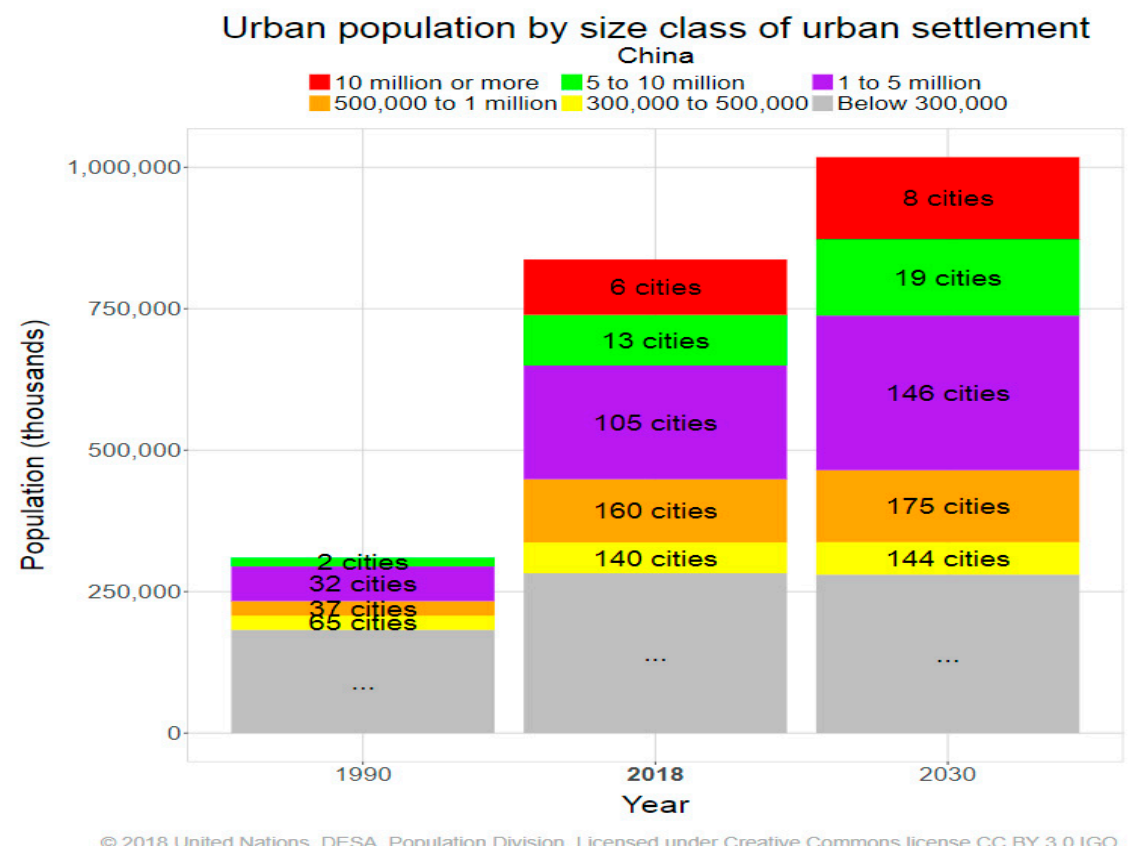

Figure 3. Major cities of China by population, 1990-2030 [24]. 


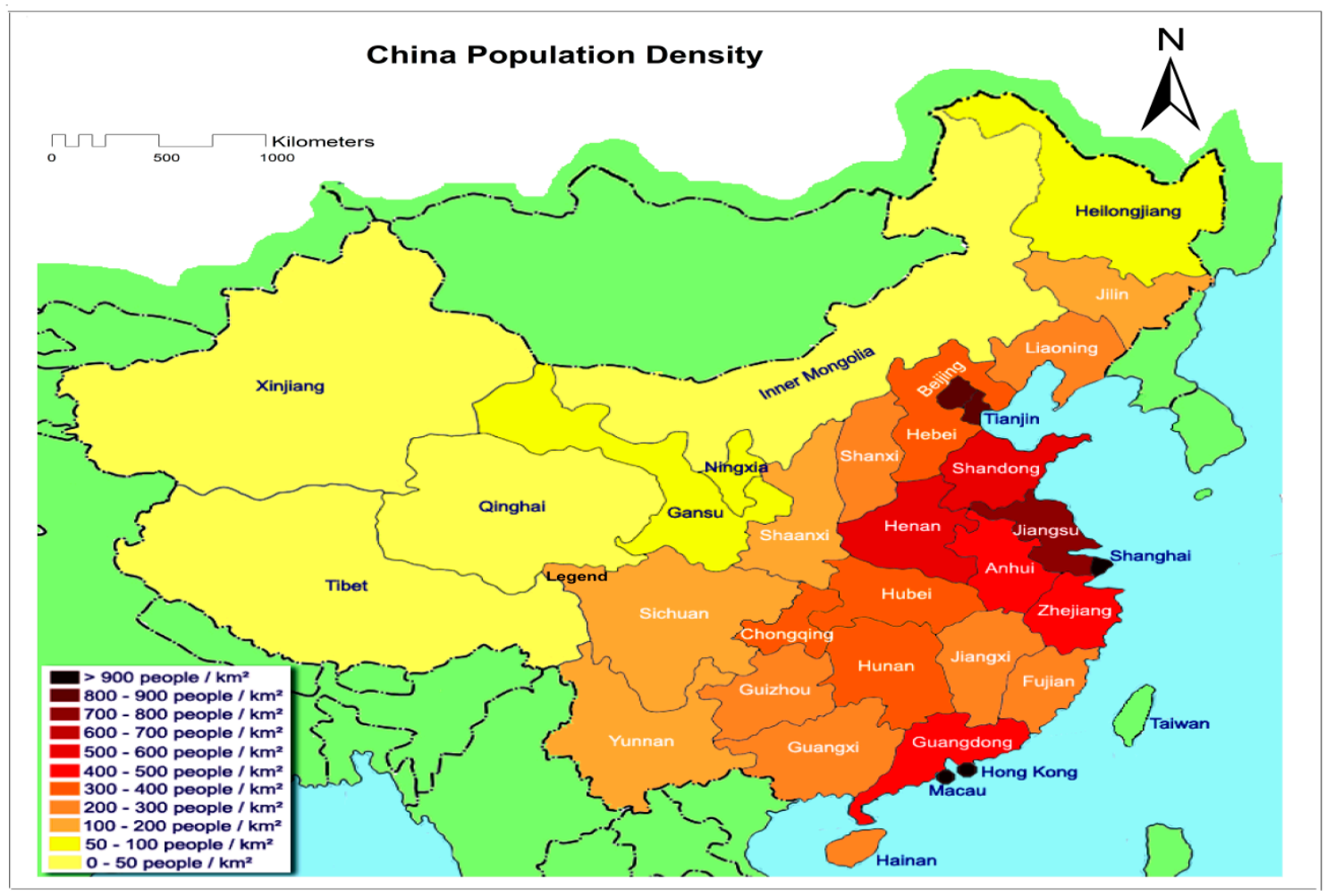

Figure 4. Population density of China [83].

Migration trends and driving forces of Chinese urbanization are distinctive from other countries of the world. The comparatively high rates of urbanization, large and growing urban-rural income gaps, existence of too many cities with fewer people, the unbalanced economic structures of cities, and strict administrative hierarchy are significant causes and driving forces of urbanization in China. Meanwhile, the greater income gap between urban and rural dwellers is the critical factor of rural-urban migration in China. Many cities have unbalanced economic structures due to the excessive development of land, and the land scarcity problem becomes more severe in China [26,29]. On the one hand, China is heading towards economic-led urbanization and globalization that enhance more productivity in capital, the labor force, information, and technology [84]. Whereas, on the other hand, China faces many problems including environmental, social and, governance issues [29], i.e., air pollution, degradation of biodiversity, water contamination and shortages [22,29-32], loss of arable land [31], energy shortages [22], and unbalanced infrastructural development [26], etc. All these problems serve as bottlenecks to restrict the sustainable development of cities in China [22], i.e., metropolitan Beijing. Various scholars have conducted many studies on China's urbanization. They concluded that sustainable urbanization is the only practical solution to curb problems and promote sustainable urban development of China $[25,29,82]$.

In the context of Pakistan, it is a developing country that has an agriculture-based economy, and is now gradually shifting towards industrial development [20]. Pakistan is the sixth most populous country in the world $[85,86]$ and the second most urbanized country in South Asia [74,87]. According to recent statistics, the population of Pakistan is rising three percent per year [88,89]. In 1951, the population of Pakistan was 33.7 million, increasing to 42.8 million in 1961, 65.3 million in 1972, 84.2 million in 1981, and 132.35 million in 1998 [34]. Today, Pakistan bears 207.7 million inhabitants [34], which may increase up to 380 million people by 2050 [88]. Simultaneously, urbanization is not a new phenomenon in Pakistan. It has been taking place since 1947, at the time of independence. However, it has been steadily increasing since 1971 [33]. During the 1972 and 1981 census of Pakistan, about 4.4\% growth rate of urban population was noted, while the rural population grew at $2.6 \%$ per annum in the same period. Due to the trend of a continuous higher urban population growth rate, urban residents' 
percentage went up from $18 \%$ to $28 \%$ between 1951 and 1981, and $32.52 \%$ was observed in 1998 [39]. Furthermore, the urban population grew at a 4.1\% rate between 2005 and 2010, and was expected to grow by $4.7 \%$ between 2010 and 2015 [33]. Today, 36.4\% of the population of Pakistan is living in urban areas [34]. This percentage will increase up to $50 \%$ by $2025[1,35,36]$ and is anticipated rise more than $50 \%$ by the end of 2050, as briefly elaborated in Figures 5 and 6 .

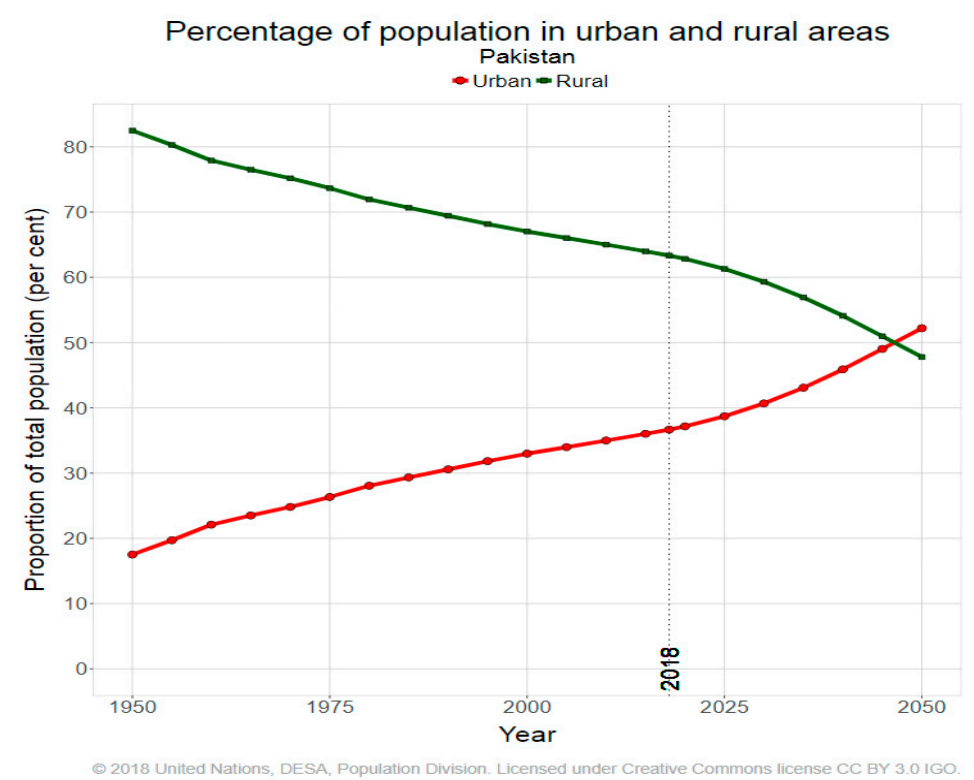

Figure 5. Urban and rural population proportion of Pakistan, 1955-2050 [24].

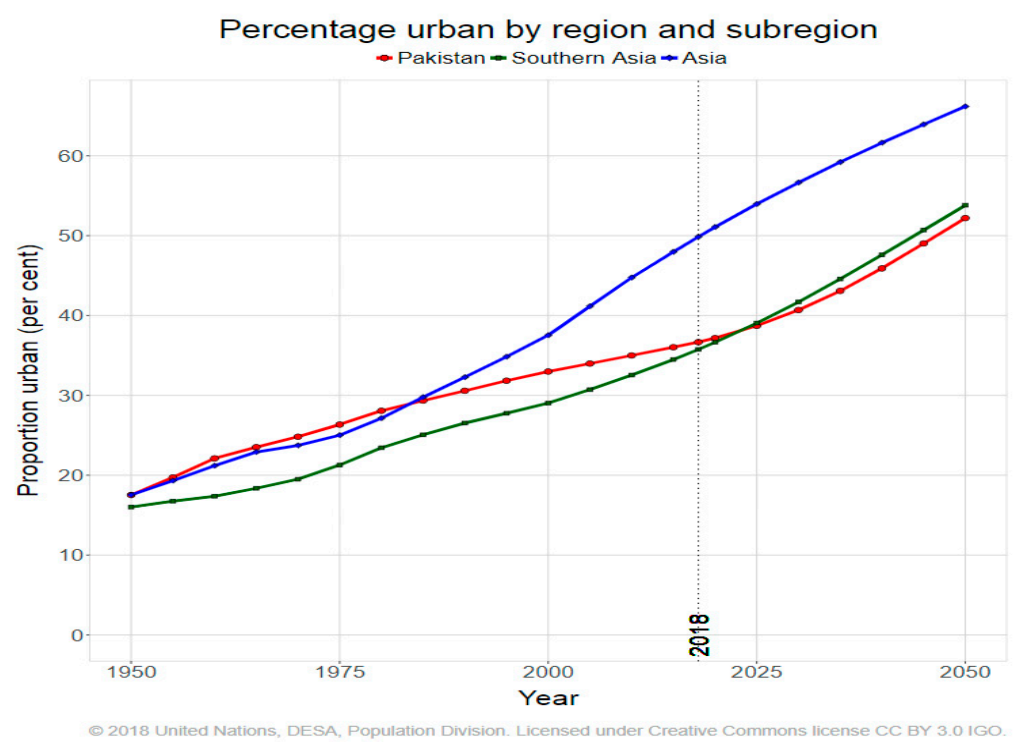

Figure 6. Pakistan and other Asian regions' urban population proportion, 1950-2050 [24].

It has also been observed that the number of urban areas increased from 238 to 515 between 1951 and 2005 in Pakistan [90]. Meanwhile, in 1990, there were four urban areas with 300,000 to 500,000 inhabitants, four cities with 500,000 to one million dwellers, three urban settlements with one to five million people, and only one city was above 10 million residents. Nowadays, the situation has changed, with 10 cities having 300,000 to 500,000 people, five urban settlements with 500,000 to one million dwellers, eight cities with one to eight million inhabitants, and two cities bearing more than 10 million urban residents in Pakistan. These numbers will be changed by 2030. Urban expansion, at an alarming rate, is mainly concentrated in 10 cities of Pakistan, which have above one million dwellers. 
All these cities contribute more than $50 \%$ to the total urban population of the country and represent the highest urban growth, in which Karachi and Lahore are the megacities containing a significant share of the urban population, as elucidated in Figures 7 and 8 . However, rapid urbanization and emerging megacities have caused enormous social changes in Pakistan.

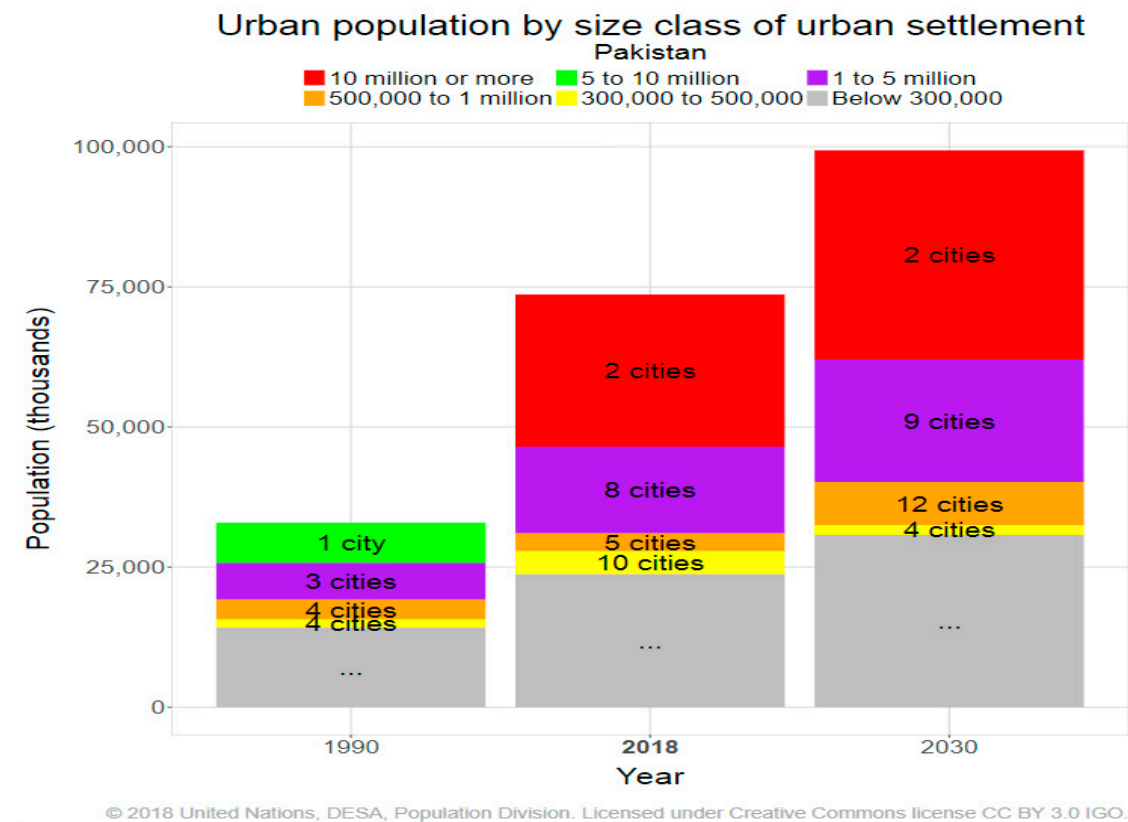

Figure 7. Major cities of Pakistan by population, 1990-2030 [24].

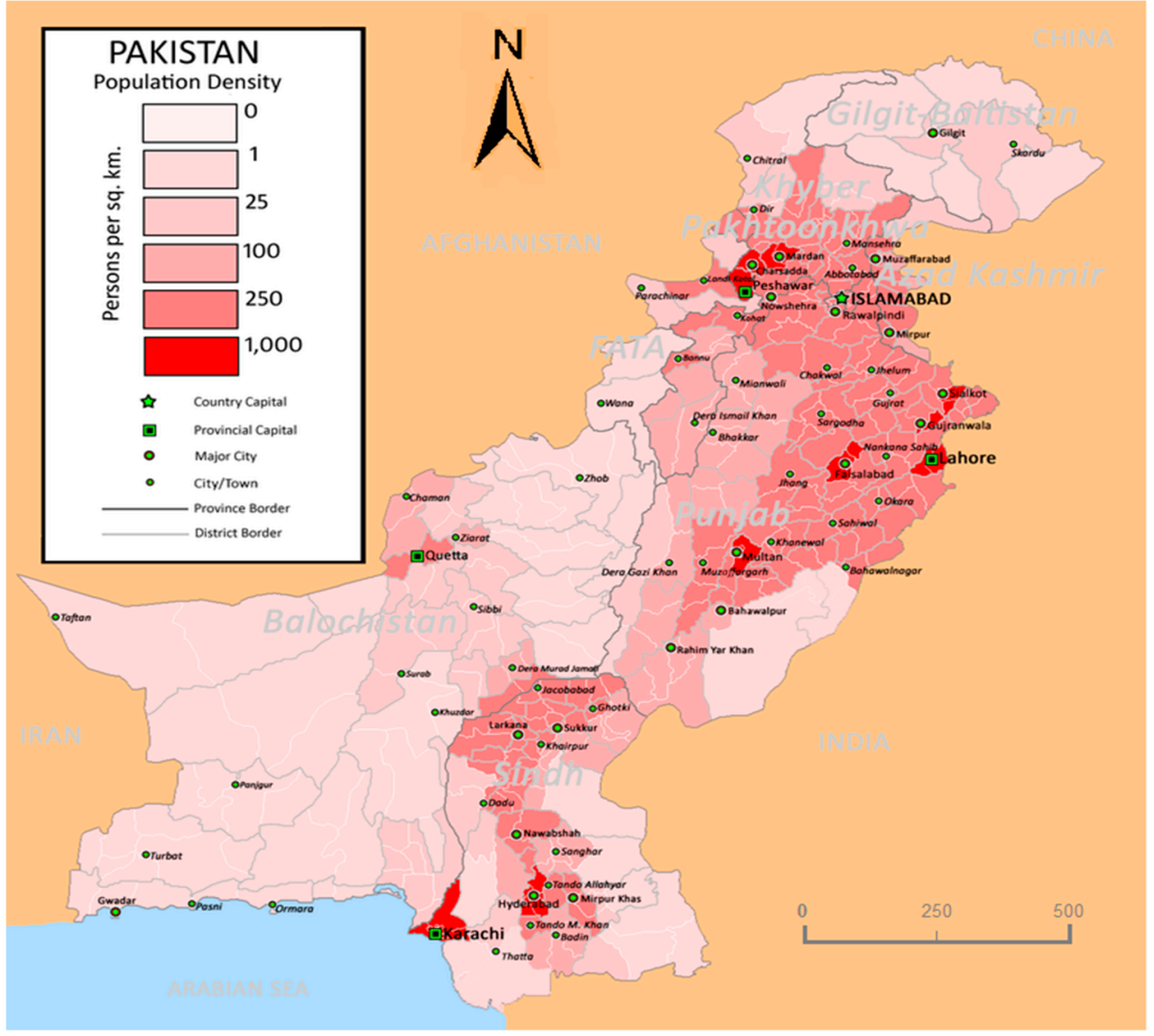

Figure 8. Population density of Pakistan [34]. 
The continuous growth of Pakistan's urbanization is attributed to two leading causes: Natural population growth and relocation/internal migration [91]. Another factor is rural-urban migration. The majority of this movement has been driven by the country's wars and conflicts. During the 1947 partition of the sub-continent, millions of Indian people migrated to Pakistan. Most of them settled in Punjab and Sindh provinces' urban areas. Later on, the 1965 and 1971 wars against India caused immigration from India and East Pakistan (Bangladesh). Then, as the anti-Soviet slogan rose in Afghanistan during the 1980s, an immense number of Afghans flowed to the western border side of Pakistan. Many of them resided in the capital cities of Khyber Pakhtunkhwa and Baluchistan Provinces, such as Peshawar and Quetta. More recently, military interventions in tribal areas of Pakistan and Afghanistan to fight against terrorism have caused an exodus of the public to various cities of Pakistan, specifically Peshawar, Quetta, and Karachi. Concurrently, local Pakistanis, mainly farmers and fishers, have been migrating due to a shortage of water in rural areas and natural disasters, such as flooding and earthquakes, which may cause them to relocate towards the cities to achieve better livelihoods. In addition, other people are migrating to gain access to better healthcare services, educational opportunities, and jobs, more often offered by cities $[39,74,88,89]$. Thus, Pakistan's urbanization has taken place in both promising and problematic conditions. On the one side, urbanization can uplift the sagging economy of the country, as the cities of Pakistan are vital sources to create and provide many employment opportunities from small and medium enterprises to large industries or high-tech zones [88]. Cities also offer higher educational opportunities and better quality of health services. However, on the other side, urbanization is putting a massive burden on the labor market and pressure on the state government in providing essential services in the urban areas. At this time, Pakistan has been struggling to accommodate the people by providing housing, education, healthcare, employment, transport, energy, and essential utility services to its urban dwellers [89,92]. If these needs cannot be met in the next 10 to 20 years, then Pakistan will face more challenges regarding urbanization. Most of the middle-income groups will rise, which are less productive contributors to society and the country's economy. Hence, such circumstances might provide fuel to the fires of radicalization [89]. Today, Pakistan faces significant challenges of sustainable development of towns while allocating or managing urban spatial structures to sustain socio-economic and environmental circumstances [39]. Karachi metropolitan city is one of them. The rapid growth of the population, urban expansion, increasing energy demand, and ecological problems are the main constraints in Pakistan's economic development $[8,40,41]$.

\section{Urban Development Situations in Beijing and Karachi Metropolitan Areas}

Beijing is the capital of China and the 12th most urbanized city in the world (indicated in Figure 9) as well as the third largest urban agglomeration in China, behind Guangzhou and Shanghai [93]. Beijing is the political, economic, and cultural center of China [94]. Currently, Beijing bears more than 20 million people, with about one-third of new migrants [94,95]. Most of the migrants come from rural areas. Beijing's permanent population grew from 8.7 million to about 15.4 million between 1978 and 2006 [96]. According to the 2010 Population Census, more than 19.6 million were living in metropolitan Beijing. Meanwhile, Beijing's urban dwellers' proportion has increased by $58 \%$ to $86.3 \%$ between 1981 and 2013 [97]. In 1998, Beijing urban agglomeration was on 66,759 ha, which is now spread over more than 265,434 ha [98]. Liu et al. [99] reported that approximately $80 \%$ of urban development has grown from 1985 to 2010 , out of which $57.14 \%$ was transformed from arable land and the remaining $23.42 \%$ was expended over the rural settlements, as illustrated in Figure 10.

Due to this rapid urban development, Beijing has faced many challenges, such as unbalanced urban development $[100,101]$, loss of arable land [96], air pollution, soil conservation, water shortages and purification challenges [97,102], and insufficient provision of public facilities [94]. Some of these problems are indicated in Figure 10. As a result, the quality balance of urban life has been decreasing day by day in Beijing. Urban sustainability is still a challenging task for the state government. Municipal 
administration has also recognized all of these issues and is working hard to curtail them under sustainable development parameters [94].

$60,000,000+$ Population

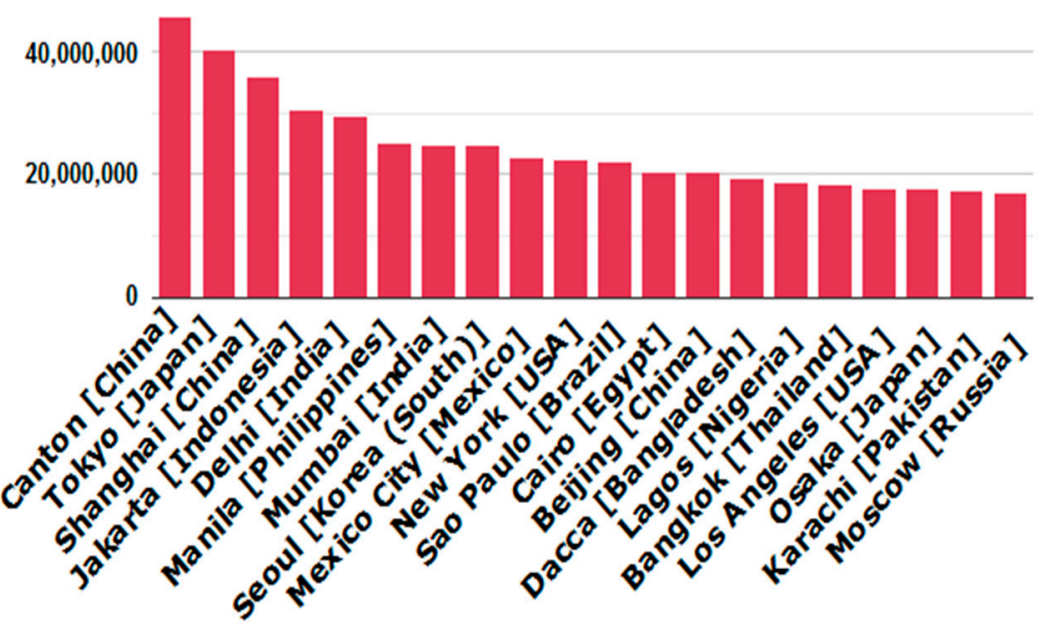

Figure 9. Top 20 urban agglomeration of the world, 2018 [103].
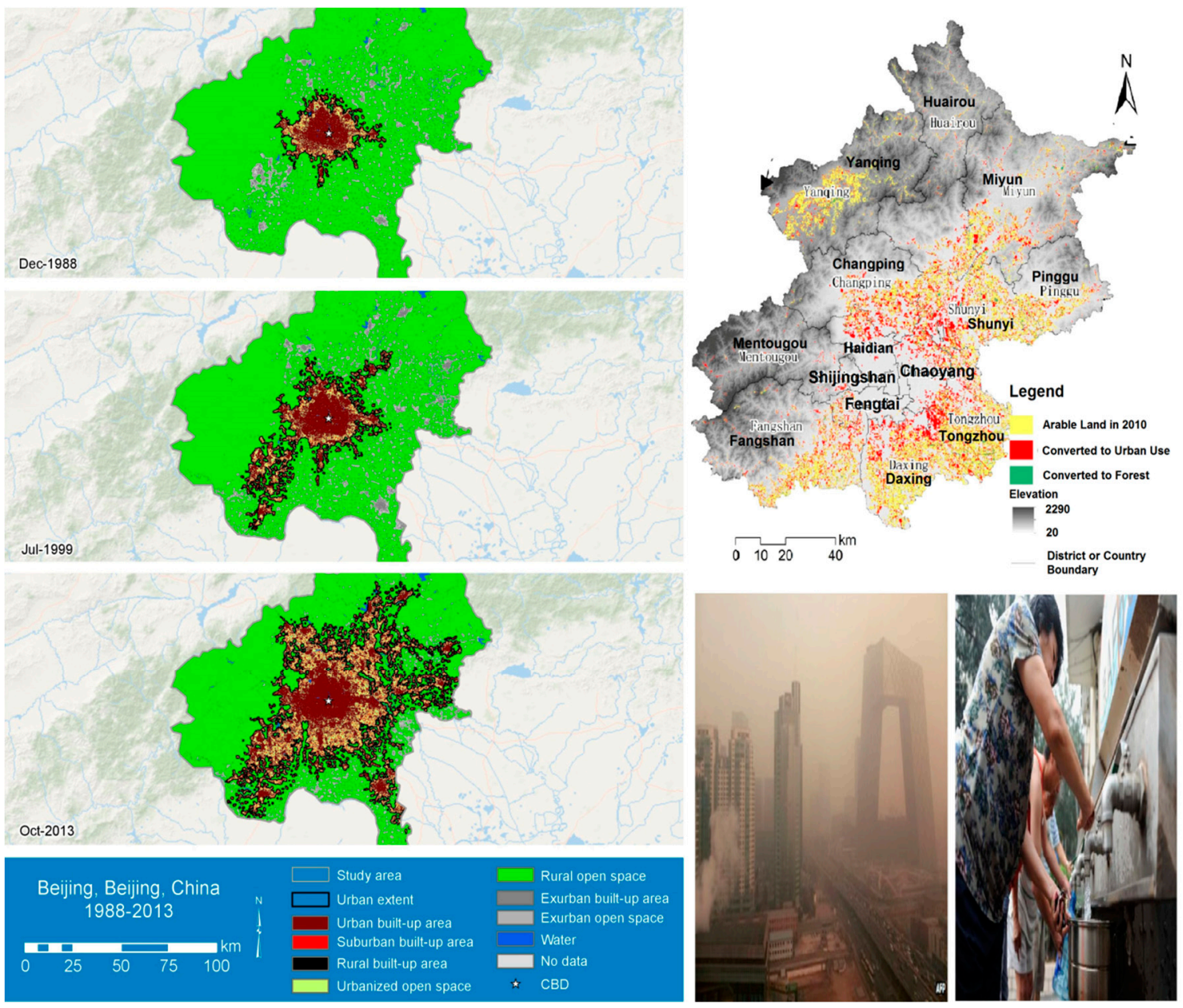

Figure 10. Urban development challenges of metropolitan Beijing $[96,99,101,104]$. 
Whereas, Karachi is one of the fastest-growing urban agglomerations of the world and it is the most urbanized city of Pakistan [105]. The metropolitan city has recently been counted as the 20th most populated city in the world [104], as pointed out in Figure 9. The population of Karachi has grown from 450,000 [37] to more than 16 million [34] between 1947 and 2017. In 1981, the population of Karachi was 5.2 million and 9.2 million in 1998, having a 4.5\% growth rate per year [37,38,106]. According to the 2017 Census Report, more than 16 million people are living in Karachi, which is expected to increase to more than 20 million by 2025. Most of the Karachi urbanization took place mainly due to three reasons: The 1947 Partition, war on terrorism, and rural-urban migration [37,38].

Moreover, the built-up land use/land cover of metropolitan Karachi also has been expanding rapidly with time [42]. It has grown from $104.258 \mathrm{~km}^{2}$ to $820.052 \mathrm{~km}^{2}$ between $1955-2010$ and has been increasing continuously. In 1992, the urban extent was noted as $516.465 \mathrm{~km}^{2}$, which was then observed to be $695.929 \mathrm{~km}^{2}$ in 1998 and further reached about $820.052 \mathrm{~km}^{2}$ in 2010 [107]. During these 55 years (1955-2010), the built-up land use/land cover of metropolitan Karachi expanded to $715.794 \mathrm{~km}^{2}$ with a $13.35 \%$ average annual growth rate, as shown in Figure 11. The urban development has mostly covered the surrounding agricultural land but also is on reclaimed land from the sea [107,108].

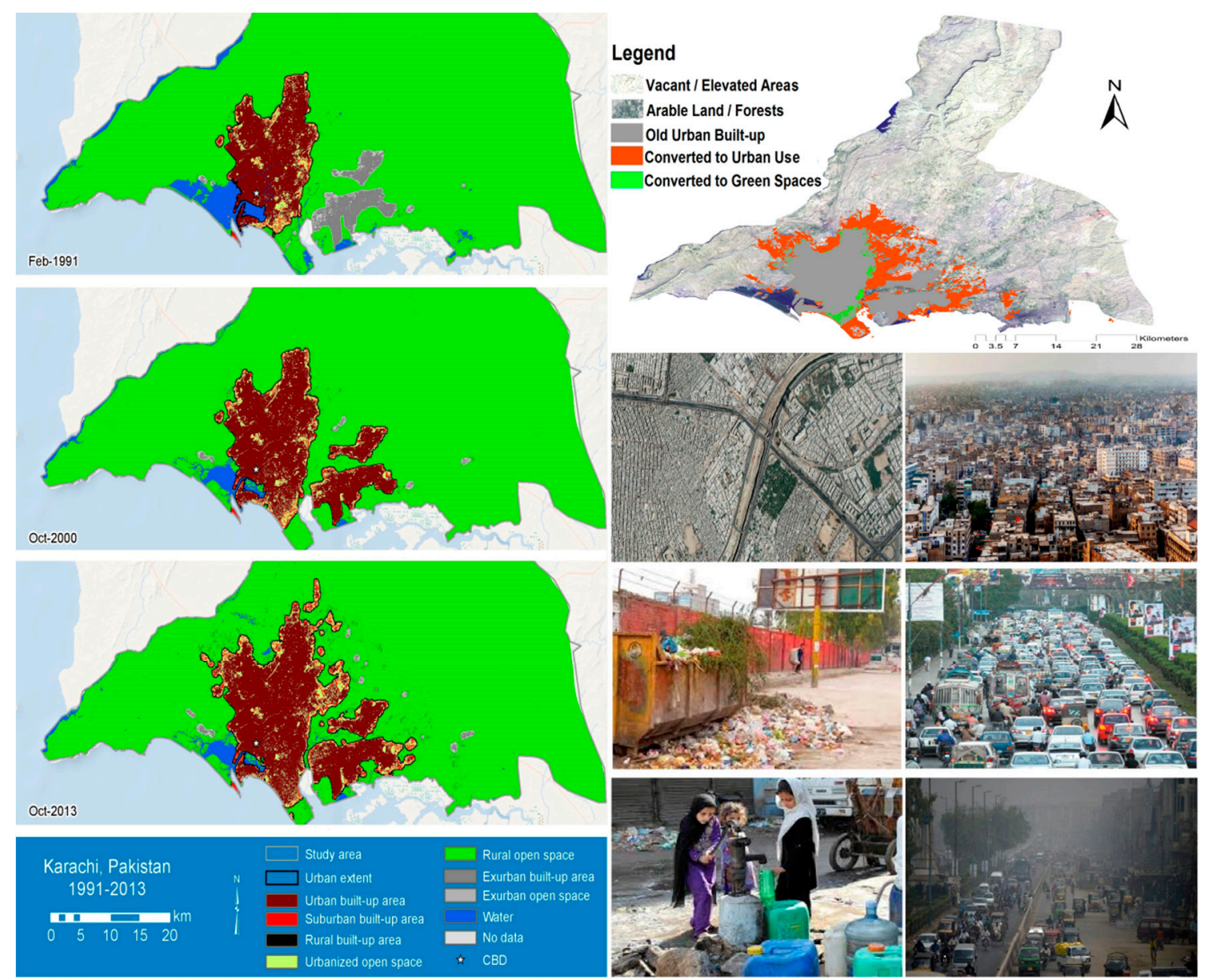

Figure 11. Urban development challenges of metropolitan Karachi $[42,43,104]$.

However, rapid urbanization is causing an improper urban expansion in metropolitan Karachi. The city bears more than 50\% informal urban built-up areas [109-111]. Before 1990, the proportion of informal land subdivisions was only $26 \%$. This proportion has grown consistently, up to $60 \%$ from 1990 to 2013, and might grow more in the future. Resultantly, spontaneous settlements; improper basic infrastructure and services; crises in drinking water, sanitation, and solid waste management facilities; inconvenient public transport; environmental pollutions; stagnation of economic activities; and poor 
governance; etc., have emerged there [42,43]. Urban sustainability has become a significant challenge in metropolitan Karachi. If these issues are not tackled in the coming decades by development authorities, then Karachi city may be listed as one of the worst cities in the world.

\section{Materials and Methods}

\subsection{Study Area}

Beijing and Karachi, metropolitan cities of China and Pakistan, were selected as the study areas. Beijing is the capital city of China. It is located on the northern side of China, at $39.97^{\circ} \mathrm{N}, 116.37^{\circ} \mathrm{E}$ coordinates, adjacent to metropolitan Tianjin and Hebei province, as indicated in Figure 12. Metropolitan Beijing is on $16,808 \mathrm{~km}^{2}$ [97,102], consisting of plain terrain to the south and mountains from north to west [112]. Beijing municipality is a provincial administrative unit [96] with 16 districts/counties, including Haidian, Xicheng, Dongcheng, Fengtai, Shunyi, Shijingshan, Mentougou, Chaoyang, Daxing, Tongzhou, Pinggu, Changping, Fangshan, Yanqing, Miyun, and Huairou, and 295 townships $[97,99]$. Furthermore, concerning its long history, culture, and political position, Beijing is one of the most developed cities in China. Beijing has multiple industrial zones such as for electronics, chemicals, machinery, automobile, textile, and light manufacturing. It contributes about RMB (Chinese Yuan) 178,794 billion to the national GDP (Gross Domestic Product) annually. Additionally, Beijing has attained numerous remarkable socio-economic achievements, reported by the Beijing Domestic Economic and Social Development Consensus in 2013 [94]. Thus, the metropolitan area is considered among the more economically developed cities of China.

Metropolitan Karachi city, however, is one of the megacities of the world and is the capital city of Sindh province, Pakistan [113]. It is situated in the southern part of Sindh province at $24.8600^{\circ} \mathrm{N}$, $67.0100^{\circ} \mathrm{E}$ world coordinates. The city of Karachi is on the coast of the Arabian Sea, surrounded by Dadu district in the north, Thatta to the northeast, and Lasbela district of Baluchistan province to the northwest direction [106], as shown in Figure 13. Metropolitan area boundaries are spread over $3527 \mathrm{~km}^{2}$ [114], comprising flat and rolling plains, containing the mountains on the west and urban extent towards the north. Two rivers, named Malir and Liyari, pass through Karachi. Malir river flows from the east towards the south by crossing the central part of Karachi. The Liyari river flows north to southwest [115]. Karachi is also counted as a division of Sindh province, which is administratively divided into five districts, i.e., Karachi east, Karachi west, Karachi central, Karachi south, and Malir. These districts are governed under Metropolitan Corporation and City District Government Karachi $[106,116]$. Districts are further sub-divided into 18 towns and 178 union councils [114].

Moreover, Karachi is a cosmopolitan city. The people have a culturally enriched background and a sense of social commitment [113]. According to the 2017 Census Report, Karachi bears $62 \%$ of the total urban population of Sindh province, 30\% of the provincial population, and $22 \%$ of Pakistan's urban population. Additionally, Karachi has the country's major seaport. It is also a significant financial hub of Pakistan that provides a unique physical and geostrategic location for socio-ecological studies [113]. The city offers enormous job opportunities based on a large-scale industrial sector that is about $71.6 \%$ of the total industrial labor of Sindh province. It is the only city of Sindh province, which contributes almost $74.8 \%$ of total industrial output to the province and also generates $78 \%$ of jobs in the private sector [37]. Therefore, Karachi city plays a vital role in the economic development of Pakistan. 


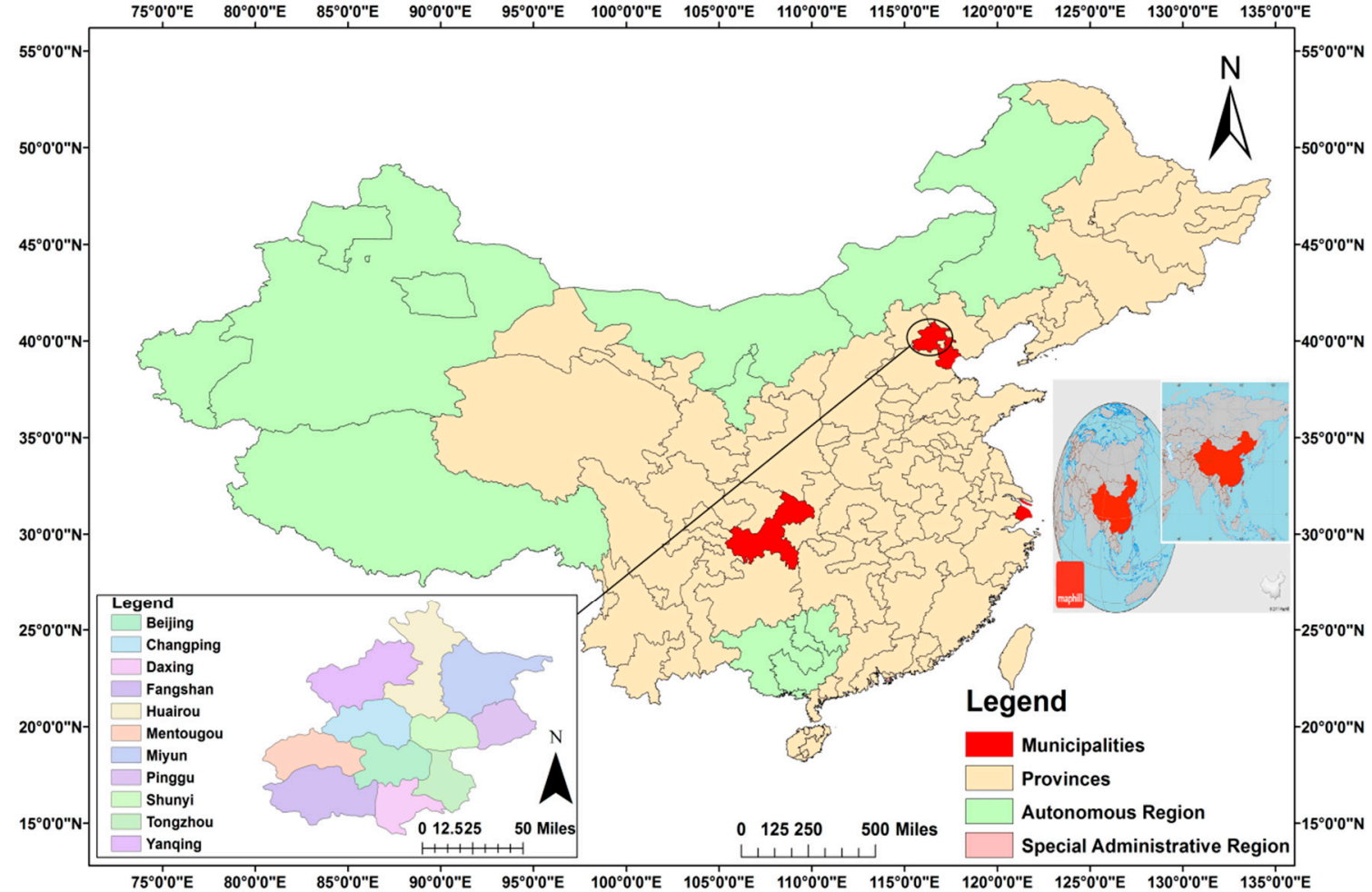

Figure 12. Location map of Beijing [97].

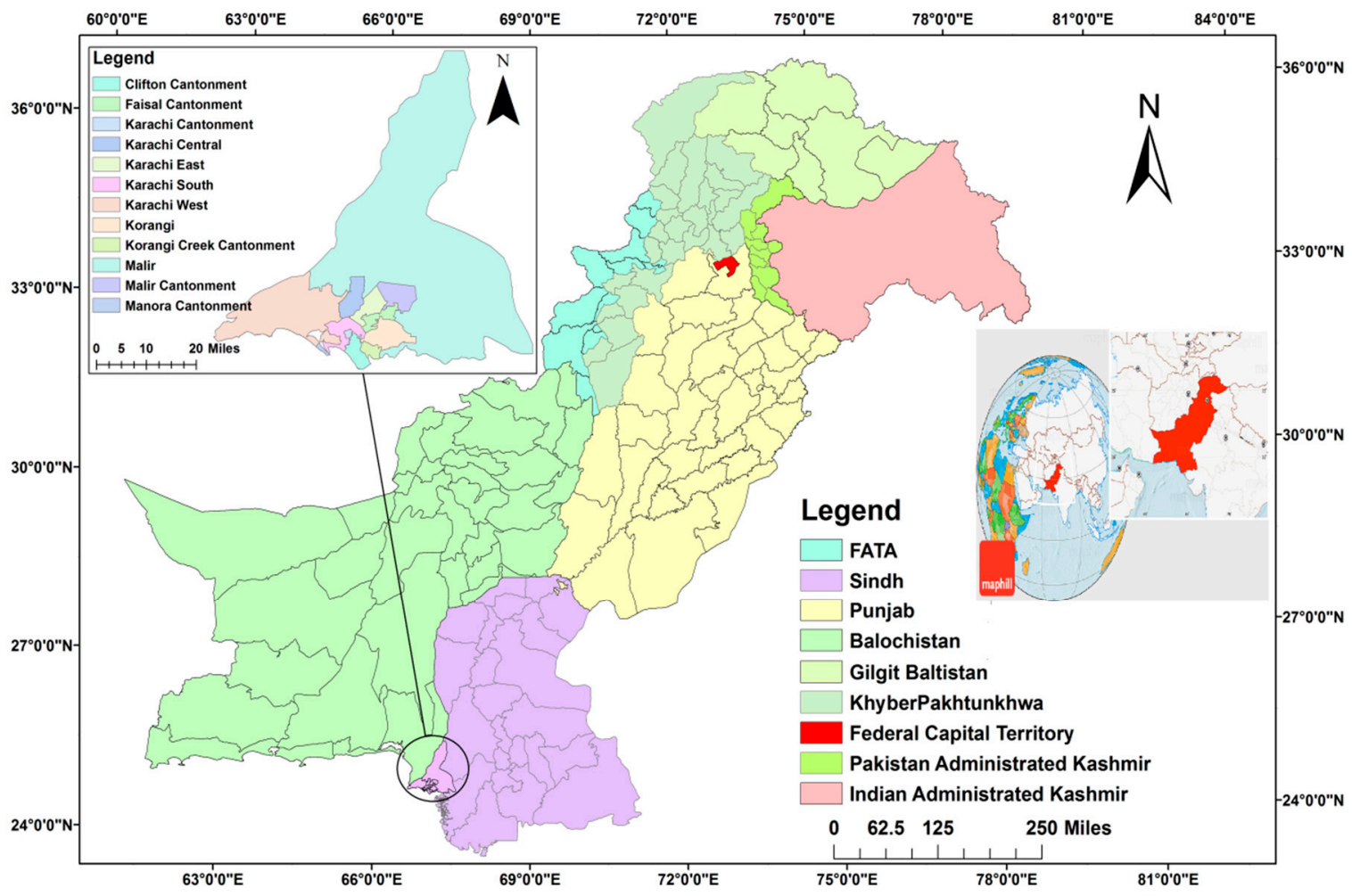

Figure 13. Location map of greater metropolitan Karachi, Pakistan [34]. 


\subsection{Methods}

\subsubsection{Urban Sustainability Index}

The Urban Sustainability Index was designed to determine the present developmental progress of the metropolitan cities in this study $[59,61,117]$. Indices were set with 36 indicators $(n=36)$ based on three aspects of sustainable development including social, economic, and environmental $[61,62,118]$, in which 11 indicators were considered for the social aspect, nine indicators for the economic aspect, and the remaining 16 indicators were undertaken for the environmental aspect, as listed in Table 1. Each indicator was then labeled as " $\mathrm{j}$ " [20,66]. Additionally, positive and negative signs were assigned to every indicator to indicate the impact of urban sustainability $[20,58,66]$. However, the calculation process of the Urban Sustainability Index was carried out by following the different phases, as shown in Figure 14.

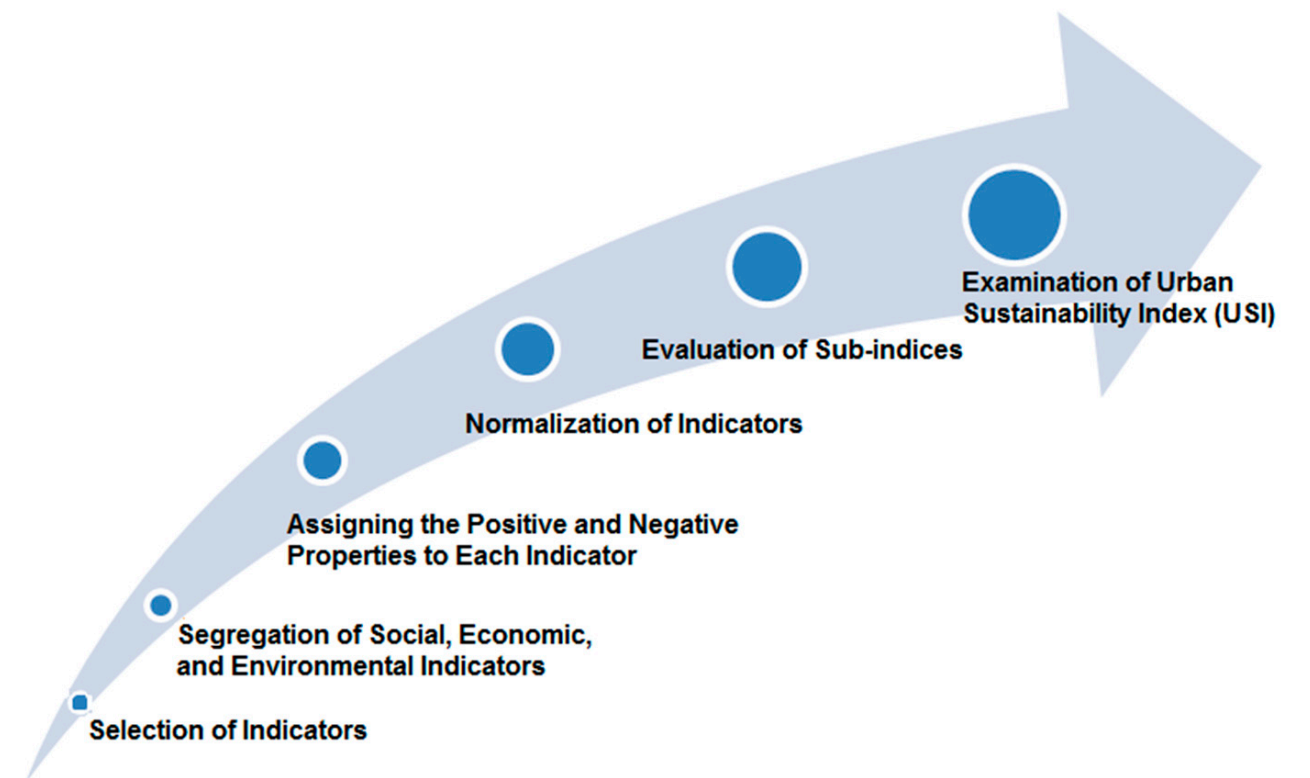

Figure 14. Calculation process of the Urban Sustainability Index.

\subsubsection{Selection of Urban Sustainability Indicators}

Sustainability indictors help to design a mechanism for measuring the sustainability level of urban areas $[51,56]$. These sustainability indicators represent the information about existing developmental conditions and sustainability performances of the cities [48,57]. Therefore, in this study, different indicators were undertaken based on current socio-economic and environmental situations of the Beijing and Karachi metropolitan cities. Indicators were selected through a detailed literature review, present urban development patterns, and availability of required data in the study area $[20,56,119]$. The indicators were chosen from the Urban Sustainable Index (USI) 2013 by the McKinsey analysis, Urban China Initiative Organization (www.urbanchinainitiative.org) [120], sustainable indictor-based study on Punjab province's cities of Pakistan by Ghalib et al. (2017) [20], and previous research of the Urban Sustainability Performances of China by Tan et al. (2018) [121] with the consent of urban planning experts, as briefly elucidated in Table 1. 
Table 1. Urban Sustainability Indicators for Metropolitan Beijing, China, and Karachi, Pakistan $[20,120,121]$.

\begin{tabular}{|c|c|c|}
\hline Indicators $(j)$ & Units & Index Properties (i) \\
\hline \multicolumn{3}{|l|}{ Social Aspect } \\
\hline Soc $_{1}$-Population & Per 10 thousand persons & Negative \\
\hline $\mathrm{Soc}_{2}-$ General middle schools & Number & Positive \\
\hline $\mathrm{Soc}_{3}$-Enrolled students in general middle school & Number & Positive \\
\hline $\mathrm{Soc}_{4}-\mathrm{New}$ enrollment in general middle school & Number & Positive \\
\hline Soc $_{5}$-Teacher-student ratio in middle school & Number & Positive \\
\hline Soc $_{6}-$ Health institutions & Number & Positive \\
\hline Soc7-Beds in health care facilities & Number & Positive \\
\hline Soc $_{8}$-Doctors & Per thousand persons & Positive \\
\hline Soc $_{9}-$ Nurses & Per thousand persons & Positive \\
\hline Soc $_{10}$-Beds in health care facilities & Per thousand persons & Positive \\
\hline Soc $_{11}$-Criminal cases detected by security departments & Number & Negative \\
\hline \multicolumn{3}{|l|}{ Economic Aspect } \\
\hline Econ $_{1}$-Per capita annual disposable income & Dollar (\$) & Positive \\
\hline Econ $_{2}-$ Per capita annual expenditures & Dollar $(\$)$ & Negative \\
\hline Econ $_{3}$-Unemployment rate & Per 10 thousand persons & Negative \\
\hline Econ $_{4}$-Government funds budgetary revenue & $\$ 100$ million & Positive \\
\hline Econ $_{5}$-Government funds budgetary expenditures & \$100 million & Positive \\
\hline Econ $_{6}$-Electricity production & 100 million kWh & Positive \\
\hline Econ 7 -Electricity consumption & 10 thousand $\mathrm{kWh}$ & Negative \\
\hline Econ$_{8}-$ Per capita electricity consumption & $\mathrm{kWh}$ & Negative \\
\hline Econ $_{9}-$ Health expenditure by government & $\$ 100$ million & Positive \\
\hline \multicolumn{3}{|c|}{ Environmental Aspect } \\
\hline Env $_{1}$-Urbanization rate & $\%$ & Negative \\
\hline Env $_{2}-$ Population density & Persons/sq.km & Negative \\
\hline Env $_{3}-$ Per capita water resources & cu.m/person & Positive \\
\hline Env $_{4}-$ Average temperature & Celsius & Negative \\
\hline Env $_{5}$-Sewage treatment capacity & 10 thousand cu.m/day & Negative \\
\hline Env $_{6}-$ Sewage treatment rate & $\%$ & Positive \\
\hline Env $_{7}$-Domestic waste removed and transported & Thousand (1000) tons & Negative \\
\hline Env $_{8}-$ Volume of waste /disposed & Thousand (1000) tons & Negative \\
\hline Env9-Percentage of waste treated & $\%$ & Positive \\
\hline $\begin{array}{l}\text { Env }_{10} \text {-Daily average of PM2.5 (Particulate Matter in the air with } \\
\text { a diameter less than or equal to } 2.5 \text { micrometers) in the year }\end{array}$ & ug/cu.m & Negative \\
\hline Env $_{11}-$ Area of urban roads & 10 thousand sq.m & Positive \\
\hline Env $_{12}-$ Area of urban roads & Per person sq.m & Positive \\
\hline Env $_{13}-$ Public transport vehicles (buses) & Number & Negative \\
\hline Env $_{14}-$ General production capacity of tap water supply & 10 thousand cu.m/day & Positive \\
\hline Env $_{15}$-Fire brigades & Number & Positive \\
\hline Env $_{16}$-Fire control vehicles & Number & Positive \\
\hline
\end{tabular}

\subsubsection{Data Collection and Analysis}

Meanwhile, secondary data sources were preferred and were extracted from information on governmental websites (i.e., the Bureau of Statistics of China and Pakistan, etc.). The previous six years of data for each indicator of Beijing and Karachi metropolitan cities were collected from 2012 to 2017 to determine the Urban Sustainability Index. Lastly, data were analyzed using the standard statistical equal-weighted method (maximum and minimum value for every indicator) [20].

\section{Statistical Calculation Method}

In previous studies, various methods were applied to analyze the obtained data of urban sustainability indicators [121-123]. However, the present study's data were calculated based on the standard statistical equal-weighted method $[20,66]$. All three social, economic, and environmental aspects based on indicators' data values were transformed into normalized values by using Equations (1) and (2). Various indicators with different characteristics and units provided simplification through this technique. The normalized values were then adjusted between 0 and 1 , which helped in weighting the 
various indicators falling within the range of 0 to 1 . Hence, the values that fell closer to 1 were considered as better sustainability, and the values that fell closer to 0 were counted as weak sustainability $[20,58]$.

$$
\begin{gathered}
I_{N, i j t}^{+}=\frac{I_{j, i t}^{+}-I_{\min , j, i}^{+}}{I_{\max , j, i}^{+}-I_{\min , j, i}^{+}} \\
I_{N, i j t}^{-}=1-\frac{I_{j, i t}^{-}-I_{\text {min }, j, i}^{-}}{I_{\max , j, i}^{-}-I_{\min , j, i}^{-}}
\end{gathered}
$$

where $I_{N, i j t}^{+}$is the normalized based indicator, with " $i$ " having a positive impact for the " $j$ " indicator group at the time (year) $t$, while $I_{N, i j t}^{-}$is the normalized based indicator, with " $i$ " having a negative impact for the " $j$ " indicator group at the time (year) t. Meanwhile, $I_{\min }^{+}$is the positive impact-based indicator with a minimum value, and $I_{\max }^{+}$is the positive impact-based indicator with a maximum value. Moreover, $I_{\min }^{-}$is the negative impact-based indicator with a minimum value, and $I_{\max }^{-}$is the negative impact-based indicator with a maximum value [20]. Subsequently, a different group of indicators, j sub-indices (IS, jt), were measured using Equation (3).

$$
I_{S, j t}=\frac{1}{N} \sum_{j, i t}^{N} I_{N, i j t}^{+}+I_{N, i j t}^{-}
$$

All three social, economic, and environmental aspects based on sustainability dimensions were assessed by Equation (3), and taken as the intermediate results. Lastly, both Beijing and Karachi metropolitan cities' Sustainability Indexes (IUSI) were calculated individually by combining sub-indices employing Equation (4).

$$
I_{U S I}=\frac{1}{N} \sum_{j, i t}^{N} S_{j, t}
$$

The urban sustainability indices were assessed, and we compared urban sustainability progresses to understand the current impact of Beijing and Karachi metropolitan cities on the human lives and surrounding environments. We also evaluated the present sustainability status of both cities using Equation (4).

More to the point, four urban sustainability classification levels were determined. The level one was set as sustainable (Level I, >0.75), and level two was counted as moderately sustainable (Level II, 0.50 to 0.75 ), whereas poorly sustainable was listed at level three (Level III, 0.25 to 0.50 ), and level four was determined as unsustainable (Level IV, <0.25) [20,66].

\section{Results}

This study was conducted measuring the existing trends in urban development at the metropolitan level, based on urban sustainability indicators. The Beijing and Karachi metropolitan cities' developmental progresses were examined using urban sustainability indices. At the same time, both cities' developmental performances were also compared in order to understand the current position of urban sustainability of these cities.

The social, economic, and environmental sub-indices of Beijing and Karachi metropolitan cities were assessed individually based on sustainability dimensions. Afterward, both Beijing's and Karachi's Sustainability Indexes (USI) were measured by combining all three sub-indices to identify urban developmental progress at the metropolitan scale. Results are briefly discussed as follows:

\subsection{Social Sub-Indices of the Metropolitan Areas}

Social sub-indices were assessed and compared between Beijing and Karachi metropolitan cities, as presented in Figure 15. 
In case of Beijing, the results revealed that the population (S-1) dimension was poorly sustainable (0.30), the middle schools indicator (S-2) was moderately sustainable (0.64), the enrolled students in middle schools (S-3) indicator was poorly sustainable (0.49), the new enrollment in middle schools indicator (S-4) was poorly sustainable (0.36), and the teacher-student ratio in the middle schools indicator (S-5) was moderately sustainable (0.50). The number of health institutions (S-6) was poorly sustainable (0.43), the total beds in health facilities indicator (S-7) was also poorly sustainable (0.43), the doctors per thousand persons' dimension (S-8) showed at Level III as poorly sustainable (0.48), nurses per thousand persons (S-9) was at poorly sustainable (0.48), the beds per thousand persons indicator (S-10) showed to be poorly sustainable (0.46), and the criminal cases detected by security departments (S-11) dimension was displaying as moderately sustainable (0.69).

Similarly, the Karachi metropolitan analysis showed that the population (S-1) dimension was unsustainable (0.24), the number of middle schools (S-2) was moderately sustainable (0.50), the previous enrolment of students in middle schools (S-3) was moderately sustainable (0.50), new students' enrollment in middle schools (S-4) was moderately sustainable (0.50), and the teacher-student ratio in the middle schools (S-5) indicator was also moderately sustainable (0.50). The number of health institutions (S-6) was poorly sustainable (0.38), the total beds in health facilities indicator (S-7) was poorly sustainable (0.34), the doctors per thousand persons indicator (S-8) was also poorly sustainable (0.43), the nurses per thousand persons (S-9) dimension showed to be poorly sustainable (0.41), the beds per thousand persons indicator (S-10) was poorly sustainable (0.34), and the criminal cases detected by security departments (S-11) indicator was determined as moderately sustainable (0.61).

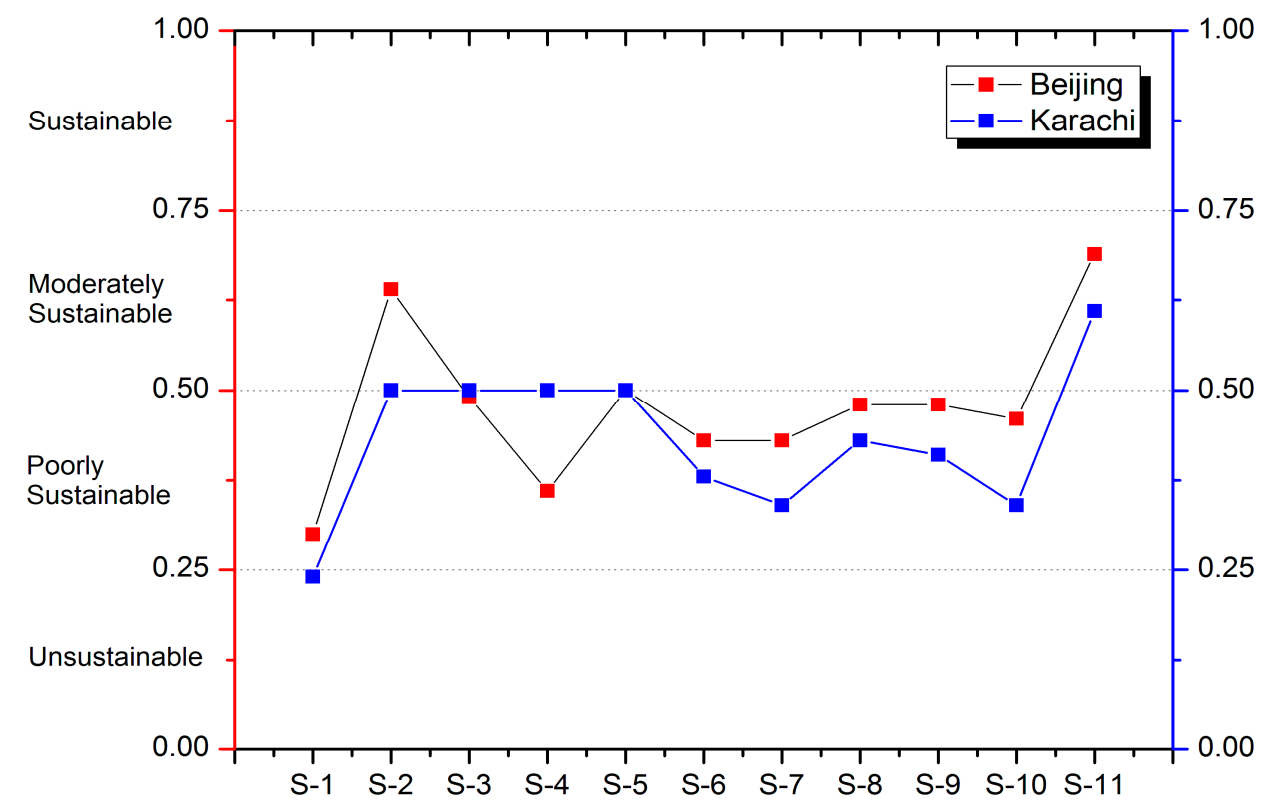

Figure 15. Sub-indices of social dimensions of metropolitan Beijing and Karachi cities.

\subsection{Economic Sub-Indices of the Metropolitan Areas}

Economic sub-indices were analyzed and compared between metropolitan Beijing and Karachi cities, as shown in Figure 16.

Results of economic sub-indices of metropolitan Beijing indicate that the per capita annual income (E-1) dimension was poorly sustainable (0.48), the per capita annual expenditures indicator (E-2) was moderately sustainable (0.53), the unemployment rate (E-3) dimension was poorly sustainable (0.37), government funds budgetary revenue (E-4) showed as moderately sustainable (0.50), and the government funds budgetary expenditures indicator (E-5) was poorly sustainable (0.49). The electricity production (E-6) dimension was moderately sustainable (0.57), general electricity consumption (E-7) was moderately sustainable (0.55), the per capita electricity consumption (S-8) dimension was also 
moderately sustainable (0.64), and the health expenditures by local government (E-9) dimension was noted as poorly sustainable (0.43).

Meanwhile, economic sub-indices of metropolitan Karachi results revealed that the per capita annual income (E-1) indicator was poorly sustainable (0.43), the per capita annual expenditures indicator (E-2) was poorly sustainable (0.39), the unemployment rate (E-3) indicator was pointed out to be poorly sustainable (0.31), government funds budgetary revenue (E-4) was also poorly sustainable (0.42), and government funds budgetary expenditures (E-5) was identified as poorly sustainable (0.41). The electricity production (E-6) indicator was at Level III as poorly sustainable (0.48), general electricity consumption (E-7) was poorly sustainable (0.49), the per capita electricity consumption (E-8) indicator was also poorly sustainable (0.47), and the health expenditures by local government (E-9) indicator was observed as poorly sustainable (0.41).

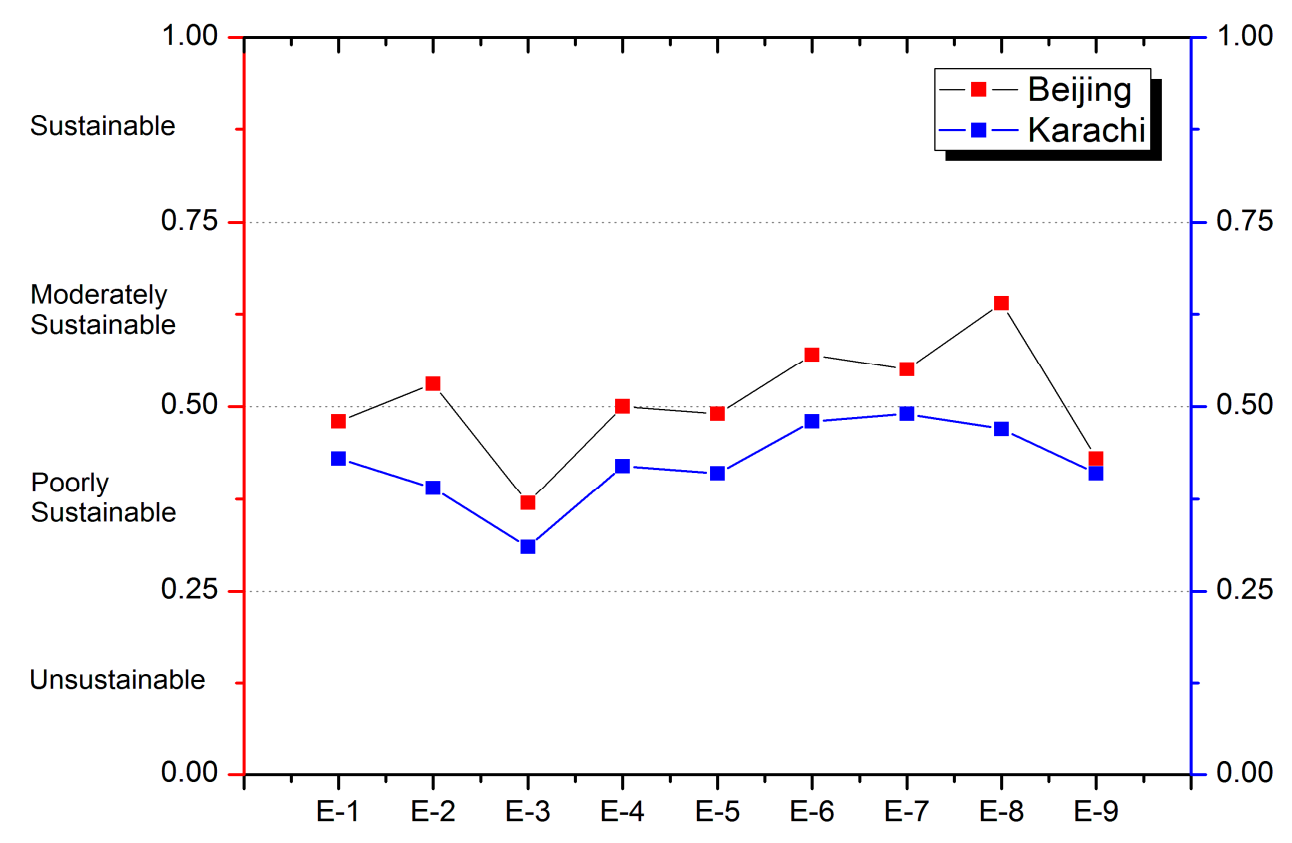

Figure 16. Sub-indices of economic dimensions of metropolitan Beijing and Karachi cities.

\subsection{Environmental Sub-Indices of the Metropolitan Areas}

Meanwhile, the environmental aspect-based sub-indices were calculated and compared between metropolitan Beijing and Karachi cities, as illustrated in Figure 17.

Environmental sub-indices of metropolitan Beijing results found that the urbanization rate (ENV-1) indicator was poorly sustainable (0.49), population density per square kilometer (ENV-2) was poorly sustainable (0.30), the per capita water resources (ENV-3) indicator was poorly sustainable (0.44), the average temperature (ENV-4) was indicated as poorly sustainable (0.48), the sewage treatment capacity (ENV-5) indicator was moderately sustainable (0.64), and sewage treatment rate (ENV-6) was poorly sustainable (0.46). The domestic waste removed and transported (ENV-7) indicator was moderately sustainable (0.55), the volume of waste disposed (ENV-8) was moderately sustainable (0.60), the percentage of waste disposed (ENV-9) was fully sustainable (0.82), the daily average of PM 2.5 (Particulate Matter in the air with a diameter less than or equal to 2.5 micrometers) in the year dimension (ENV-10) was examined as poorly sustainable (0.36), the total area of urban roads (ENV-11) indicator was moderately sustainable (0.61), and the area of urban roads per capita (ENV-12) was noted as moderately sustainable (0.55). Additionally, the public transport buses (ENV-13) indicator was at Level I as completely sustainable (0.78), the general production capacity of tap water supply (ENV-14) was moderately sustainable (0.64), the fire brigades (ENV-15) indicator was moderately sustainable (0.59), and the fire control vehicles (ENV-16) indicator was also highlighted as moderately sustainable (0.58). 
Simultaneously, Karachi's environmental sub-indices' outcomes show that the urbanization rate (ENV-1) dimension was poorly sustainable (0.42), population density per square kilometer (ENV-2) was unsustainable (0.21), the per capita water resources (ENV-3) dimension was poorly sustainable $(0.36)$, the average temperature (ENV-4) was showing as poorly sustainable (0.47), the sewage treatment capacity (ENV-5) dimension was unsustainable (0.23), and sewage treatment rate (ENV-6) was also unsustainable (0.24). The domestic waste removed and transported (ENV-7) dimension was moderately sustainable (0.56), the volume of waste disposed (ENV-8) was poorly sustainable (0.41), the percentage of waste disposed (ENV-9) was unsustainable (0.21), the daily average of PM 2.5 in the year dimension (ENV-10) was assessed as moderately sustainable (0.52), the total area of urban roads (ENV-11) dimension was moderately sustainable (0.50), and the area of urban roads per capita (ENV-12) was observed as moderately sustainable (0.50). In addition, the public transport buses (ENV-13) dimension was moderately sustainable (0.57), the general production capacity of tap water supply (ENV-14) was poorly sustainable (0.41), the fire brigades (ENV-15) dimension was identified as unsustainable (0.23), and the fire control vehicles (ENV-16) dimension was also pointed out to be unsustainable (0.25).

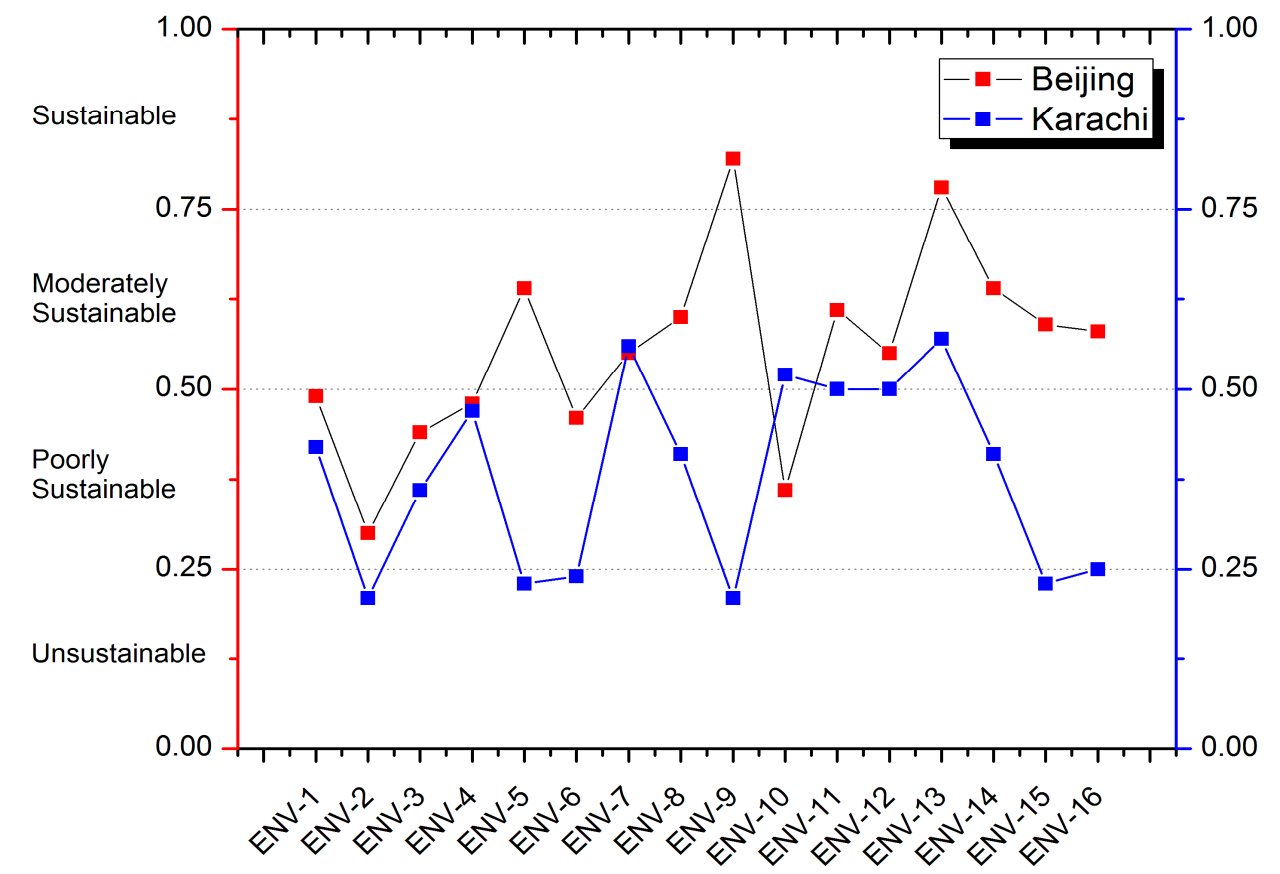

Figure 17. Sub-indices of environmental dimensions of metropolitan Beijing and Karachi cities.

\subsection{Combined Social, Economic, and Environmental Sub-Indices of the Metropolitan Areas}

All three social, economic, and environmental dimension-based sub-indices' outputs were combined, and we compared the sustainability level among these indicators, as shown in Figure 18. Eleven dimensions were selected for social aspects, nine for economic aspects, and 16 variables were selected for the environmental group. Sustainable, moderately sustainable, poorly sustainable, and unsustainable levels of each dimension were observed.

As the result for social dimensions, Beijing's indicators have still not secured a sustainable level (Level I, >0.75). Three indicators (number of middle schools, teacher-student ratio in middle schools, and criminal cases detected by security departments) were moderately sustainable (Level II, 0.50 to 0.75), and eight indicators (population, enrolled students in middle schools, new enrollment in middle schools, number of health institutions, total beds in health facilities, doctors per thousand persons, nurses per thousand persons, and beds per thousand persons) were poorly sustainable (Level III, 0.25 to 0.50 ). Meanwhile, metropolitan Karachi did not have any dimension at a sustainable (Level I, $>0.75$ ) level; five indicators (number of middle schools, enrolled students in middle schools, new 
enrollment in middle schools, teacher-student ratio in middle schools, and criminal cases detected by security departments) of Karachi were moderately sustainable (Level II, 0.50 to 0.75 ); five dimensions (number of health institutions, total beds in health facilities, doctors per thousand persons, nurses per thousand persons, and beds per thousand persons) were poorly sustainable (Level III, 0.25 to 0.50 ); and only one dimension (population) of metropolitan Karachi was noted as unsustainable (Level IV, $<0.25$ ).

Meanwhile, the result of the economic indicators showed that not any of the economic dimensions of Beijing were completely sustainable (Level I, $>0.75$ ), five dimensions (per capita annual expenditures, government funds budgetary revenue, electricity production, general electricity consumption, and per capita electricity consumption) were moderately sustainable (Level II, 0.50 to 0.75 ), and the remaining four dimensions (per capita annual income, unemployment rate, government funds budgetary expenditures, and health expenditures by local government) were poorly sustainable (Level III, 0.25 to 0.50 ), whereas all nine economic indicators of metropolitan Karachi were observed as poorly sustainable (Level III, 0.25 to 0.50 ).

Likewise, the environmental dimensions result revealed that the two indicators (percentage of waste disposed and public transport buses) for Beijing were attained at the first level as sustainable (Level I, >0.75), eight indicators (sewage treatment capacity, sewage treatment rate, volume of waste disposed, total area of urban roads, area of urban roads per capita, general production capacity of tap water supply, fire brigades, and fire control vehicles) were moderately sustainable (Level II, 0.50 to 0.75 ), and the remaining six indicators (urbanization rate, population density per square kilometer, per capita water resources, average temperature, sewage treatment rate, and daily average of PM 2.5 in the year) were poorly sustainable (Level III, 0.25 to 0.50 ). In the case of Karachi, no environmental dimension was listed as sustainable (Level $\mathrm{I},>0.75$ ), five dimensions (domestic waste removed and transported, daily average of PM 2.5 in the year, total area of urban roads, area of urban roads per capita, and public transport buses) were moderately sustainable (Level II, 0.50 to 0.75 ), and five indicators (urbanization rate, per capita water resources, average temperature, volume of waste disposed, and general production capacity of tap water supply) were poorly sustainable (Level III, 0.25 to 0.50 ). Of the remaining six indicators (population density per square kilometer, sewage treatment capacity, sewage treatment rate, percentage of waste disposed, fire brigades, and fire control vehicles) of metropolitan Karachi, almost $38 \%$ were unsustainable (Level IV, $<0.25$ ).

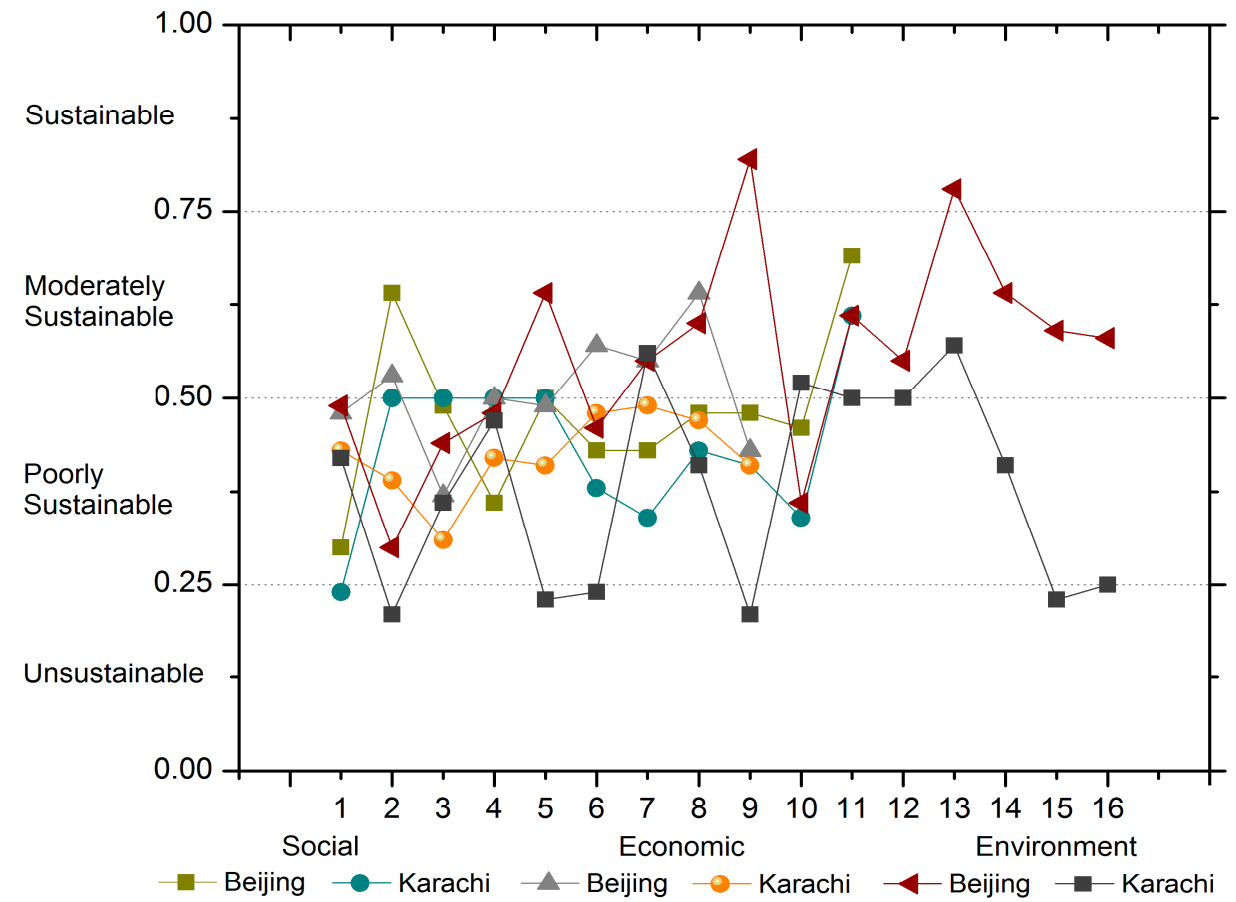

Figure 18. Combined sub-indices of social, economic, and environmental dimensions of metropolitan Beijing and Karachi cities. 


\subsection{Urban Sustainability Index of the Metropolitan Areas}

Finally, integrated metropolitan Beijing and Karachi cities' Urban Sustainability Index was measured by employing the outputs of social, economic, and environmental sub-indices. The social sub-indices of Beijing showed as poorly sustainable (0.49), and Karachi was also poorly sustainable (0.34). Whereas, Beijing's economic sub-indices were moderately sustainable (0.53), and Karachi's were unsustainable (0.25). Additionally, the environmental sub-indices of Beijing were moderately sustainable (0.56), and Karachi's were poorly sustainable (0.30). Various urban sustainability levels of metropolitan Beijing and Karachi are presented in Figure 19.

The result of the Urban Sustainability Index revealed that metropolitan Beijing is placed at the second level (Level II, 0.50 to 0.75 ) of urban sustainability, while metropolitan Karachi stood at the third level (Level III, 0.25 to 0.50 ) of urban sustainability [20,66]. In conclusion, it was observed that, presently, metropolitan Beijing development is moderately sustainable (0.53), and metropolitan Karachi development is still poorly sustainable (0.30).

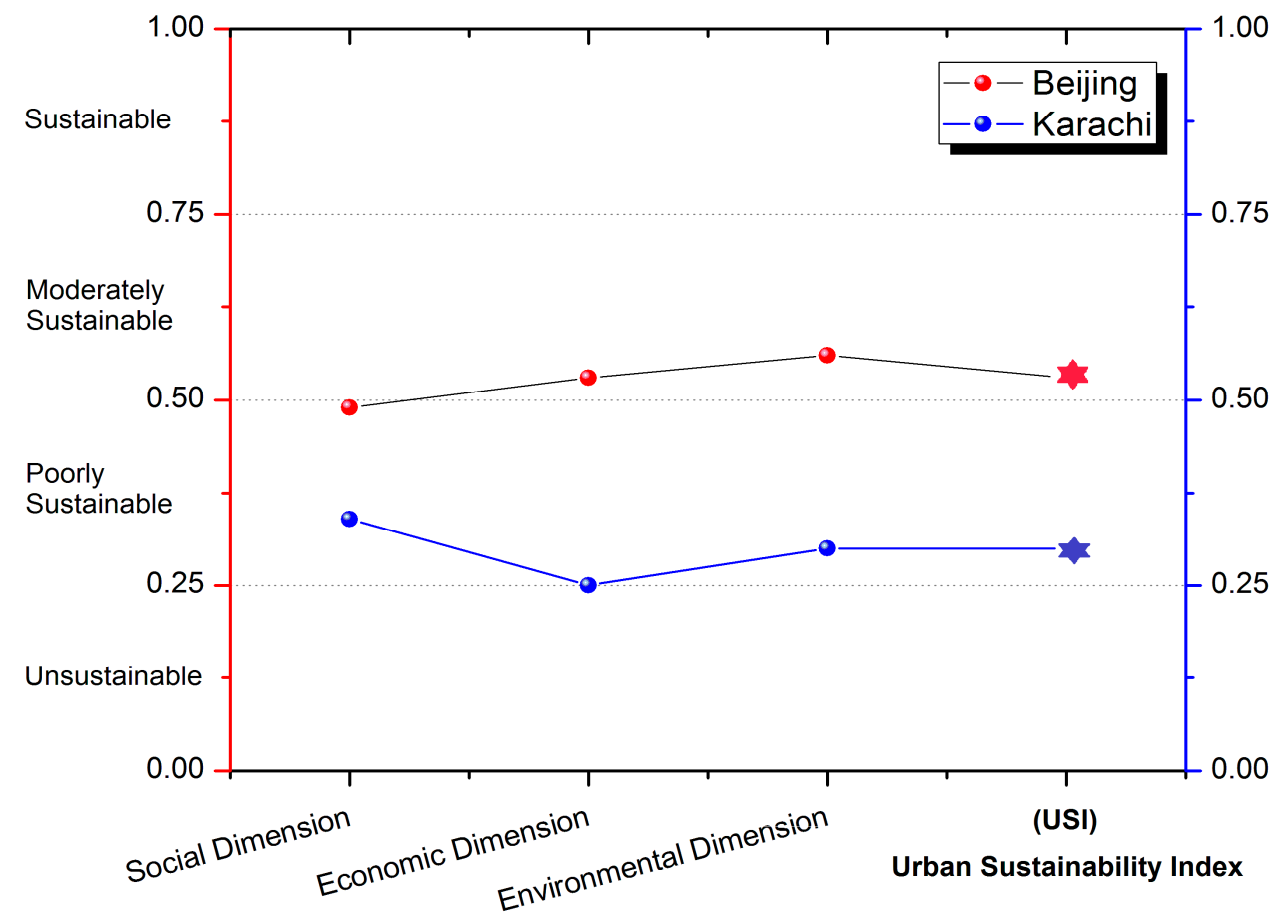

Figure 19. Urban Sustainability Index of metropolitan Beijing and Karachi cities.

\section{Discussion}

In this study, the Urban Sustainability Index was designed and used to assess the existing urban development trends of metropolitan Beijing and Karachi cities. The index system was set based on three aspects of sustainable development; social, economic, and environmental $[61,62,118]$. A total of $36(n=36)$ indicators were adopted, out of which 11 indicators were related to the social aspect, nine dimensions were economic, and 16 indicators were related to the environmental aspect, respectively, as listed in Table 1. These indicators were selected through a detailed literature review, experts' opinion, urban development patterns, and availability of required data in the study area $[20,56,119,124]$.

The data were collected from governmental websites (i.e., Bureau of Statistics of China and Pakistan, etc.). Data from the previous six years (2012-2017) were obtained to determine the Urban Sustainability Index of both metropolitan cities. Subsequently, data were analyzed employing the standard statistical equal-weighted method [20].

The Urban Sustainability Index results revealed that metropolitan Beijing's developmental progress is much better than metropolitan Karachi's in all aspects of urban sustainability. Social 
development of both metropolitan Beijing (0.49) and Karachi (0.34) cities attained a 'poorly sustainable' status. The economic stability of Beijing (0.53) is much more satisfactory than metropolitan Karachi (0.25). Beijing's environmental development (0.56) is about to attain sustainable status, and Karachi (0.30) is far behind, with about $38 \%$ of environmental indicators as unsustainable. However, overall, Beijing's developmental progress is moderately sustainable (0.53 or Level II, 0.50 to 0.75$)$, whereas metropolitan Karachi's developmental performances are still poorly sustainable (0.30 or Level III, 0.25 to 0.50$)[20,66]$. Thus, much attention is needed in the case of metropolitan Karachi, while Beijing also needs advancement in urban development quality.

More significantly, metropolitan Beijing administrators have been working to regularly improve progress in socio-economic and environmental development. They have conducted several studies, and most of them are implemented. Authorities have also initiated different urban development programs to attain sustainable status for the city of Beijing. However, this study provides the current sustainability status of metropolitan Beijing and points out the development progress and its challenges to Beijing's development authorities for further necessary action. Meanwhile, metropolitan Karachi has been facing many challenges since 1947, after the independence of Pakistan. Fewer studies have been conducted on urban development trends in this city, and these have been hardly implemented by metropolitan authorities. Resultantly, Karachi has emerged as one of the least developed cities in the world. Thus, this study has examined the present developmental rank of metropolitan Karachi in the Urban Sustainability Index. The study leads policymakers, city administrators, and other stakeholders of metropolitan Karachi to understand how the city has undergone critical situations, the reasons behind them, and how to mitigate them.

For the advancement of urban development progress and its quality balance at the metropolitan level in the context of the Urban Sustainability Index, we recommend the following strategies.

As the social sub-indices of both metropolitan Beijing and Karachi cities were observed to be poorly sustainable, it is, therefore, recommended that the administrative authorities of Beijing and Karachi should focus on social dimensions on a priority basis to increase the performances in social development. Beijing authorities should especially emphasize "population, enrolled students in middle schools, new enrolment in middle schools, number of health institutions, total beds in health facilities, doctors per thousand persons, nurses per thousand persons, and hospitals' beds per thousand persons" indicators; whereas metropolitan Karachi administrators should focus on the "number of health institutions, total beds in health facilities, doctors per thousand persons, nurses per thousand persons, and hospital beds per thousand persons" dimensions. However, the population indicator of Karachi should be addressed first, as top priority social dimension.

Moreover, the economic sustainability sub-indices of Beijing are much better than that of metropolitan Karachi. However, there is still a need for improvement in order to catch the first level of the Urban Sustainability Index. Therefore, Beijing administrators need to give priority to the "per capita annual income, unemployment rate, government funds budgetary expenditures, and health expenditures by local government" indicators while performing the tasks for improving economic development. Meanwhile, Karachi economic development-based sub-indices are ranked as unsustainable, at the fourth or bottom level of the Urban Sustainability Index. These performances in the economic development of Karachi are inferior. Metropolitan Karachi authorities should concentrate on all economic indicators as they are mainly noted at the third stage of the Urban Sustainability Index.

Additionally, presently, metropolitan Beijing development performances concerning environmental dimensions are admirable but still one stage behind attaining the status of urban sustainability. Thus, they should more specifically work on the "urbanization rate, population density per square kilometer, per capita water resources, average temperature, sewage treatment rate, and the daily average of PM 2.5 in the year" environmental dimensions. For Karachi, about $38 \%$ of the total 16 indicators face very critical situations, and the other remaining indicators also need much improvement. Hence, the "population density per square kilometer, sewage treatment capacity, sewage treatment rate, percentage of waste disposed of, fire brigades, and fire control vehicle" dimensions 
should be undertaken on a priority basis without any delay; whereas the "urbanization rate, per capita water resources, average temperature, the volume of waste disposed of, and overall production capacity of tap water supply environmental" dimensions of Karachi should be treated according to urban sustainability requirements.

Lastly, further studies can be conducted on various cities of China and Pakistan; as well as other parts of the developing world, or developed countries at the primary, medium, and small scale in the context of urban sustainability; to examine existing urban development trends and their challenges using various appropriate techniques including the standard statistical equal-weighted method. Notably, much attention is needed by scholars in the case of Pakistan.

\section{Conclusions}

This study focused on examining the urban development trends based on sustainability indicators at the metropolitan level. A comparative study was conducted considering metropolitan Beijing and Karachi cities of China and Pakistan. The socio-economic and environmental development progress of both cities were assessed using the data taken from different governmental websites through the Urban Sustainability Index $[59,61,117]$. As a result, the social development of both Beijing and Karachi cities were found to be poorly sustainable. The economic growth of Beijing was moderately sustainable, and that of metropolitan Karachi was poorly sustainable. In addition, Beijing's environmental development was moderately sustainable, and Karachi's was poorly sustainable. Overall, the urban developmental progress of Beijing was moderately sustainable and Karachi's was poorly sustainable. Most of Beijing's social, economic, and environmental indicators were progressing consistently; while all three aspects of urban sustainability indicators for Karachi were progressing less. This study concluded that the urban development of Beijing is much better than metropolitan Karachi in terms of socio-economic and environmental development. However, there is still a need for improvement to achieve the title of sustainability. Karachi city faces challenges in all sectors including social, economic, and environmental. Every single indicator of these sectors requires massive improvement for securing the first level in the Urban Sustainability Index. Lastly, study findings may be useful to guide policymakers, urban managers, and other officials for developing possible strategies to mitigate urban development issues appropriately, and to increase both Metropolitan cities' developmental progress concerning the Urban Sustainability Index, to be listed as sustainable urban areas.

Author Contributions: Conceptualization: M.Y.M. and Z.Y.; methodology: Z.Y., M.Y.M., and S.K.; validation: Z.Y., M.Y.M., and S.K.; formal analysis: M.Y.M. and Z.A.L.; investigation: M.Y.M.; resources: Z.Y.; data curation: M.Y.M.; writing-original draft preparation: M.Y.M.; writing—review and editing: Z.Y., S.K., and Z.A.L.; supervision: Z.Y.; funding acquisition: Z.Y. All authors have read and agreed to the published version of the manuscript.

Funding: This research was funded by National Key R\&D Program of China, grant number (2017YFC0702301 in 2017YFC0702300).

Acknowledgments: Authors would like to thank Ying Long (Associate Professor, Department of Urban Planning, School of Architecture, Tsinghua University, Beijing, China) as well as the concerned government officials of metropolitan Karachi for providing necessary information and guidance while conducting research activities, and are specially grateful to Abdul Raheem (Tsinghua University, Beijing, China), who assisted in the proof reading of this paper.

Conflicts of Interest: The authors declare no conflict of interest.

\section{References}

1. Aziz, A.; Ahmad, I.; Mayo, S.M.; Hameed, R.; Nadeem, O. Urbanization and Its Impacts on Founded Areas of Big Cities in Pakistan: Case Studies of "Ichra" and "Sanda" Areas in Lahore. Tech. J. Univ. Eng. Technol. Taxila Pak. 2015, 20, 71-75.

2. Zhang, X.Q. The Trends, Promises and Challenges of Urbanisation in the World. Habitat Int. 2016, 54, $241-252$. [CrossRef]

3. Malik, N.; Asmi, F.; Ali, M.; Rahman, M.M. Major Factors Leading Rapid Urbanization in China and Pakistan: A Comparative Study. J. Soc. Sci. Stud. 2017, 5, 148. [CrossRef] 
4. Cohen, B. Urbanization in Developing Countries: Current Trends, Future Projections, and Key Challenges for sustainability. Technol. Soc. 2006, 28, 63-80. [CrossRef]

5. Cobbinah, P.B.; Erdiaw-Kwasie, M.O.; Amoateng, P. Africa's Urbanisation: Implications for Sustainable Development. Cities 2015, 47, 62-72. [CrossRef]

6. Aboukorin, A.A.; Al-shihri, F.S. Rapid Urbanization and Sustainability in Saudi Arabia: The Case of Dammam Metropolitan Area. J. Sustain. Dev. 2015, 8, 52. [CrossRef]

7. Singh, V.P.; Maheshwari, B.; Thoradeniya, B. Options and Strategies for Balanced Development for Liveable Cities: An Epilogue; Springer: Cham, Switzerland, 2016. [CrossRef]

8. Minallah, M.N.; Ghaffar, A.; Rafique, M.; Mohsin, M. Urban Growth and Socio-Economic Development in Gujranwala, Pakistan: A Geographical Analysis. Pak. J. Sci. 2016, 68, 176-183.

9. Akin, A.; Clarke, K.C.; Berberoglu, S. The Impact of Historical Exclusion on the Calibration of the SLEUTH Urban Growth Model. Int. J. Appl. Earth Obs. Geoinf. 2014, 27, 156-168. [CrossRef]

10. Wu, J.; Jenerette, G.D.; Buyantuyev, A.; Redman, C.L. Quantifying Spatiotemporal Patterns of Urbanization: The Case of the Two Fastest Growing Metropolitan Regions in the United States. Ecol. Complex. 2011, 8, 1-8. [CrossRef]

11. Sakieh, Y.; Salmanmahiny, A.; Jafarnezhad, J.; Mehri, A.; Kamyab, H.; Galdavi, S. Evaluating the Strategy of Decentralized Urban Land-Use Planning in a Developing Region. Land Use Policy 2015, 48, 534-551. [CrossRef]

12. Bloom, D.E.; Canning, D.; Fink, G. Urbanization and the Wealth of Nations. Sci. Rep. 2008, 319, $772-775$. [CrossRef] [PubMed]

13. Al-Fugara, A.; Al-Shabeeb, A.R.; Al-Shawabkeh, Y.; Al-Amoush, H.; Al-Adamat, R. Simulation and Prediction of Urban Spatial Expansion in Highly Vibrant Cities Using the Sleuth Model: A Case Study of Amman Metropolitan, Jordan. Theor. Empir. Res. Urban Manag. 2018, 13, 37-56.

14. Tanguay, G.A.; Rajaonson, J.; Lefebvre, J.F.; Lanoie, P. Measuring the Sustainability of Cities: An Analysis of the Use of Local Indicators. Ecol. Ind. 2010, 10, 407-418. [CrossRef]

15. Van Dijk, M.P.; Mingshun, Z. Sustainability Indices as a Tool for Urban Managers, Evidence from Four Medium-Sized Chinese Cities. Environ. Impact Assess. Rev. 2005, 25, 667-688. [CrossRef]

16. Makinde, O.O. Urbanization, Housing and Environment: Megacities of Africa. Int. J. Dev. Sustain. 2012, 1, 976-993.

17. Pravitasari, A.E. Study on Impact of Urbanization and Rapid Urban Expansion in Java and Jabodetabek Megacity, Indonesia. Ph.D. Thesis, Kyoto University, Kyoto, Japan, 2015. [CrossRef]

18. Klopp, J.M.; Petretta, D.L. The Urban Sustainable Development Goal: Indicators, Complexity and the Politics of Measuring Cities. Cities 2017, 63, 92-97. [CrossRef]

19. Huang, S.L.; Wong, J.H.; Chen, T.C. A Framework of Indicator System for Measuring Taipei's Urban Sustainability. Landsc. Urban Plan. 1998. [CrossRef]

20. Ghalib, A.; Qadir, A.; Ahmad, S.R. Evaluation of Developmental Progress in Some Cities of Punjab, Pakistan, Using Urban Sustainability Indicators. Sustainability 2017, 9, 1473. [CrossRef]

21. Han, L.; Zhou, W.; Li, W.; Li, L. Impact of Urbanization Level on Urban Air Quality: A Case of Fine Particles (PM2.5) in Chinese Cities. Environ. Pollut. 2014, 194, 163-170. [CrossRef]

22. Yin, K.; Wang, R.; An, Q.; Yao, L.; Liang, J. Using Eco-Efficiency as an Indicator for Sustainable Urban Development: A Case Study of Chinese Provincial Capital Cities. Ecol. Ind. 2014, 36, 665-671. [CrossRef]

23. Gong, J.; Hu, Z.; Chen, W.; Liu, Y.; Wang, J. Urban Expansion Dynamics and Modes in Metropolitan Guangzhou, China. Land Use Policy 2018, 72, 100-109. [CrossRef]

24. DESA/Population Division. World Urbanization Prospects-Population Division-United Nations. Available online: https://population.un.org/wup/ (accessed on 28 December 2018).

25. Tan, Y.; Xu, H.; Jiao, L.; Ochoa, J.J.; Shen, L. A Study of Best Practices in Promoting Sustainable Urbanization in China. J. Environ. Manag. 2017, 193, 8-18. [CrossRef] [PubMed]

26. Shang, J.; Li, P.; Li, L.; Chen, Y. The Relationship between Population Growth and Capital Allocation in Urbanization. Technol. Forecast. Soc. Chang. 2018, 135, 249-256. [CrossRef]

27. Li, S.; Li, X.; Liu, X.; Wu, Z.; Ai, B.; Wang, F. Simulation of Spatial Population Dynamics Based on Labor Economics and Multi-Agent Systems: A Case Study on a Rapidly Developing Manufacturing Metropolis. Int. J. Geogr. Inf. Sci. 2013, 27, 2410-2435. [CrossRef]

28. Li, L.; Zhou, H. Manufacturing Practices in China. Int. J. Prod. Econ. 2013. [CrossRef] 
29. Tan, Y.; Xu, H.; Zhang, X. Sustainable Urbanization in China: A Comprehensive Literature Review. Cities 2016, 55, 82-93. [CrossRef]

30. Wu, W.; Zhao, S.; Zhu, C.; Jiang, J. A Comparative Study of Urban Expansion in Beijing, Tianjin and Shijiazhuang over the Past Three Decades. Landsc. Urban Plan. 2015, 134, 93-106. [CrossRef]

31. Cui, X.; Fang, C.; Liu, H.; Liu, X. Assessing Sustainability of Urbanization by a Coordinated Development Index for an Urbanization-Resources-Environment Complex System: A Case Study of Jing-Jin-Ji Region, China. Ecol. Ind. 2019, 96, 383-391. [CrossRef]

32. Kunzmann, K.R. Urbanization in China: Learning from Europe? A European Perspective. Int. J. Urban Sci. 2015, 19, 119-135. [CrossRef]

33. Blank, J.; Clary, C.; Nichiporuk, B. Drivers of Long-Term Insecurity and Instability in Pakistan; Rand Corporation: Santa Monica, CA, USA, 2014; Available online: http://www.jstor.org/stable/10.7249/j.ctt1287mdc (accessed on 5 March 2019).

34. Shahbaz, M.; Chaudhary, A.R.; Ozturk, I. Does Urbanization Cause Increasing Energy Demand in Pakistan? Empirical Evidence from STIRPAT Model. Energy 2017, 122, 83-93. [CrossRef]

35. Pakistan Bureau of Statistics. Pakistan Bureau of Statistics|6th Population and Housing Census. Pak. Bur. Stat. 2017. [CrossRef]

36. Malik, S.; Wahid, J. Rapid Urbanization: Problems and Challenges for Adequate Housing in Pakistan. J. Sociol. Soc. Work 2014, 2, 87-110. [CrossRef]

37. Hasan, A. Emerging Urbanisation Trends: The Case of Karachi Emerging Urbanization Trends. Report 2016. Available online: https://www.theigc.org/wp-content/uploads/2016/12/Hasan-2016-Academic-Paper.pdf (accessed on 8 March 2019).

38. Qureshi, I.A.; Huapu, L.U. Urban Transport and Sustainable Transport Strategies. Tsinghua Sci. Technol. 2007, 12, 309-317. [CrossRef]

39. Jan, B.; Iqbal, M. Urbanization Trend and Urban Population Projections Of Pakistan Using Weighted Approach. Sarhad J. 2008, 24, 173-180.

40. Alam, S. Globalization, Poverty and Environmental Degradation: Sustainable Development in Pakistan. J. Sustain. Dev. 2010, 3, 103-114. [CrossRef]

41. Kim, K.H.; Pauleit, S. Landscape Character, Biodiversity and Land Use Planning: The Case of Kwangju City Region, South Korea. Land Use Policy 2007, 24, 264-274. [CrossRef]

42. Mathur, T. Karachi: An Informal City. Report 2013, No. 2. Available online: http//www.jmi.ac.in/ (accessed on 8 March 2019).

43. World Bank Group. Transforming Karachi into a Livable and Competitive Megacity: A City Diagnostic and Transformation Strategy; World Bank Group: Washington, DC, USA, 2018. [CrossRef]

44. Cristina, A.; Cristina, M.; Elena, C.S. Assessment of the Sustainable Urban Development Level through the Use of Indicators of Sustainability. Theor. Empir. Res. Urban Manag. 2011, 6, 78-87.

45. Mangi, M.Y.; Chandio, I.A.; Talpur, M.A.H.; Shaikh, F.A. Urban Land Use Planning Trend and Sustainable Challenges in Socio-Economic Development. Mehran Univ. Res. J. Eng. Technol. 2018. [CrossRef]

46. Gu, C.; Hu, L.; Cook, I.G. China's Urbanization in 1949-2015: Processes and Driving Forces. Chin. Geogr. Sci. 2017, 27, 847-859. [CrossRef]

47. Brundtland, G. Report of the World Commision on Environement and Development: Our Common Future. Oxf. Pap. 1987. [CrossRef]

48. Xu, Z.; Coors, V. Combining System Dynamics Model, GIS and 3D Visualization in Sustainability Assessment of Urban Residential Development. Build. Environ. 2012. [CrossRef]

49. Verma, P.; Raghubanshi, A.S. Urban Sustainability Indicators: Challenges and Opportunities. Ecol. Ind. 2018, 93, 282-291. [CrossRef]

50. Ekins, P. Environmental Sustainability: From Environmental Valuation to the Sustainability Gap. Prog. Phys. Geogr. 2011. [CrossRef]

51. Huang, L.; Wu, J.; Yan, L. Defining and Measuring Urban Sustainability: A Review of Indicators. Landsc. Ecol. 2015. [CrossRef]

52. Mori, K.; Yamashita, T. Methodological Framework of Sustainability Assessment in City Sustainability Index (CSI): A Concept of Constraint and Maximisation Indicators. Habitat Int. 2015, 45, 10-14. [CrossRef]

53. Komeily, A.; Srinivasan, R.S. A Need for Balanced Approach to Neighborhood Sustainability Assessments: A Critical Review and Analysis. Sustain. Cities Soc. 2015. [CrossRef] 
54. Abu-Ghazalah, S. The Sustainable City Development Plan for Aqaba, Jordan. J. Dev. Soc. 2008. [CrossRef]

55. Rasoolimanesh, S.M.; Badarulzaman, N.; Jaafar, M. City Development Strategies (CDS) and Sustainable Urbanization in Developing World. Procedia-Soc. Behav. Sci. 2012. [CrossRef]

56. Hiremath, R.B.; Balachandra, P.; Kumar, B.; Bansode, S.S.; Murali, J. Indicator-Based Urban Sustainability-A Review. Energy Sustain. Dev. 2013, 17, 555-563. [CrossRef]

57. Winston, N.; Pareja Eastaway, M. Sustainable Housing in the Urban Context: International Sustainable Development Indicator Sets and Housing. Soc. Ind. Res. 2008. [CrossRef]

58. Choon, S.W.; Siwar, C.; Pereira, J.J.; Jemain, A.A.; Hashim, H.S.; Hadi, A.S. A Sustainable City Index for Malaysia. Int. J. Sustain. Dev. World Ecol. 2011. [CrossRef]

59. Michael, F.L.; Noor, Z.Z.; Figueroa, M.J. Review of Urban Sustainability Indicators Assessment-Case Study between Asian Countries. Habitat Int. 2014, 44, 491-500. [CrossRef]

60. Kitchin, R.; Lauriault, T.P.; McArdle, G. Knowing and Governing Cities through Urban Indicators, City Benchmarking and Real-Time Dashboards. Reg. Stud. Reg. Sci. 2015, 2, 6-28. [CrossRef]

61. Zinatizadeh, S.; Monavari, S.M.; Azmi, A.; Sobhanardakani, S. Evaluation and Prediction of Sustainability of Urban Areas: A Case Study for Kermanshah City, Iran. Cities 2017, 66, 1-9. [CrossRef]

62. Kwatra, S.; Kumar, A.; Sharma, P.; Sharma, S.; Singhal, S. Benchmarking Sustainability Using Indicators: An Indian Case Study. Ecol. Ind. 2016, 61, 928-940. [CrossRef]

63. Lu, C.; Xue, B.; Lu, C.; Wang, T.; Jiang, L.; Zhang, Z.; Ren, W. Sustainability Investigation of Resource-Based Cities in Northeastern China. Sustainability 2016, 8, 1058. [CrossRef]

64. Huang, L.; Yan, L.; Wu, J. Assessing Urban Sustainability of Chinese Megacities: 35 Years after the Economic Reform and Open-Door Policy. Landsc. Urban Plan. 2016, 145, 57-70. [CrossRef]

65. Gonzalez-Garcia, S.; Manteiga, R.; Moreira, M.T.; Feijoo, G. Assessing the Sustainability of Spanish Cities Considering Environmental and Socio-Economic Indicators. J. Clean. Prod. 2018, 178, 599-610. [CrossRef]

66. Sun, X.; Liu, X.; Li, F.; Tao, Y.; Song, Y. Comprehensive Evaluation of Different Scale Cities' Sustainable Development for Economy, Society, and Ecological Infrastructure in China. J. Clean. Prod. 2017, 163, S329-S337. [CrossRef]

67. Repetti, A.; Desthieux, G. A Relational Indicatorset Model for Urban Land-Use Planning and Management: Methodological Approach and Application in Two Case Studies. Landsc. Urban Plan. 2006. [CrossRef]

68. Opschoor, H.; Reijnders, L. Towards Sustainable Development Indicators. In Search of Indicators of Sustainable Development; Springer Science \& Business Media: Wien, Austria, 2011. [CrossRef]

69. Rosales, N. Towards a Design of Sustainable Cities: Incorporating Sustainability Indicators in Urban Planning. In Proceedings of the 46th ISOCARP Congress, Nairobi, Kenya, 19-23 September 2010; pp. 1-11.

70. Yigitcanlar, T.; Dur, F.; Dizdaroglu, D. Towards Prosperous Sustainable Cities: A Multiscalar Urban Sustainability Assessment Approach. Habitat Int. 2015, 45, 36-46. [CrossRef]

71. Braulio-Gonzalo, M.; Bovea, M.D.; Ruá, M.J. Sustainability on the Urban Scale: Proposal of a Structure of Indicators for the Spanish Context. Environ. Impact Assess. Rev. 2015, 53, 16-30. [CrossRef]

72. Singh, R.K.; Murty, H.R.; Gupta, S.K.; Dikshit, A.K. Development of Composite Sustainability Performance Index for Steel Industry. Ecol. Ind. 2007. [CrossRef]

73. Malkina-Pykh, I.G. Integrated Assessment Models and Response Function Models: Pros and Cons for Sustainable Development Indices Design. Ecol. Ind. 2002. [CrossRef]

74. Wagan, S.A.; Memon, Q.; Noonari, S. A Comparative Study of Urbanization's Impact on Agricultural Land Between China, Pakistan, and Germany. J. Resour. Dev. Manag. 2018, 41, 44-50.

75. UN. World Urbanization Prospects—Population Division-United Nations. 2019. Available online: https: //population.un.org/wpp/ (accessed on 5 March 2019).

76. Wang, J.; He, D. Sustainable Urban Development in China: Challenges and Achievements. Mitig. Adapt. Strateg. Glob. Chang. 2015, 20, 665-682. [CrossRef]

77. Sun, D.; Zhou, L.; Li, Y.; Liu, H.; Shen, X.; Wang, Z.; Wang, X. New-Type Urbanization in China: Predicted Trends and Investment Demand for 2015-2030. J. Geogr. Sci. 2017, 27, 943-966. [CrossRef]

78. National Bureau of Statistics of China. China Statistical Yearbook; China Statistics Press: Beijing, China, 2018. Available online: http://www.stats.gov.cn/tjsj/ndsj/2018/indexeh.htm (accessed on 15 December 2018).

79. Lin, J.; Cai, J.; Han, F.; Han, Y.; Liu, J. Underperformance of Planning for Peri-Urban Rural Sustainable Development: The Case of Mentougou District in Beijing. Sustainability 2016, 8, 858. [CrossRef] 
80. World Bank Group. World Bank: Population, Total|Data. 2018. Available online: https://data.worldbank.org/ indicator/SP.POP.TOTL?end=2017\&locations=CN\&start=2017\&view=bar (accessed on 15 December 2018).

81. Che, M.; Liu, W.; Tao, X. Evolution and Assessment on China's Urbanization 1960-2010: Under-Urbanization or over-Urbanization? Habitat Int. 2013. [CrossRef]

82. Liu, X.; Song, Y.; Wu, K.; Wang, J.; Li, D.; Long, Y. Understanding Urban China with Open Data. Cities 2015, 47, 53-61. [CrossRef]

83. Live China Population. Current Population of China-Countrymeters. 2018. Available online: http: //countrymeters.info/en/China\#facts (accessed on 16 December 2018).

84. Wang, H.; Gu, C.-L. Challenges and Problems: China's Urban Governance. Chin. Geogr. Sci. 2002, 12, 152-156. [CrossRef]

85. GoP. Pakistan Economic Survey. Pak. Econ. Surv. Rep. 2014. [CrossRef]

86. Ferrer, M. Karachi: Megacity of Woes. The New School for Public Engagement Report. 2015. Available online: https://www.academia.edu/13184139/Karachi_City_of_Woes (accessed on 16 March 2019).

87. UNESCO-Islamabad. Pakistan: UNESCO Country Programming Document 2013-2017. United Nations Educational, Scientific and Cultural Organaization Report. 2017, p. 86. Available online: http://unesco.org. pk/documents/2013/PAKISTAN_CPD.pdf (accessed on 18 March 2019).

88. Kugelman, M. Urbanisation in Pakistan: Cause s and Consequences. Report 2013, No. January. Available online: https://noref.no/Publications/Regions/Pakistan/Urbanisation-in-Pakistan-causes-and-consequences/ (language)/eng-US (accessed on 9 March 2019).

89. Jabeen, N.; Farwa, U.; Jadoon, M. Urbanization in Pakistan: A Governance Perspective. J. Res. Soc. Pak. 2017, 54, 127-136.

90. Minstry of Environment Government of Pakistan. Land Use Atlas of Pakistan; Report; Minstry of Environment Government of Pakistan: Islamabad, Pakistan, 2004; pp. 1-70.

91. Arif, G.M.; Hamid, S. Urbanization, City Growth and Quality of Life in Pakistan. Eur. J. Soc. Sci. 2009, 10, 196-215.

92. Hinds, R. Urbanisation and Conflict in Pakistan. International Crisis Group-Pakistan Report. 2014, pp. 1-9. Available online: https://gsdrc.org/publications/urbanisation-and-conflict-in-pakistan/ (accessed on 3 April 2019).

93. China Provinces, Prefectures, Counties, Cities, Districts, Townships, Urban Areas-Population Statistics in Maps and Charts. 2017. Available online: https://www.citypopulation.de/en/china/ (accessed on 19 December 2018).

94. Wei, Y.; Huang, C.; Lam, P.T.I.; Sha, Y.; Feng, Y. Using Urban-Carrying Capacity as a Benchmark for Sustainable Urban Development: An Empirical Study of Beijing. Sustainability 2015, 7, 3244-3268. [CrossRef]

95. Ru, M.; Tao, S.; Smith, K.; Shen, G.; Shen, H.; Huang, Y.; Chen, H.; Chen, Y.; Chen, X.; Liu, J.; et al. Direct Energy Consumption Associated Emissions by Rural-to-Urban Migrants in Beijing. Environ. Sci. Technol. 2015, 49, 13708-13715. [CrossRef]

96. Tan, M.; Guy, M.R.; Li, X. Urban Spatial Development and Land Use in Beijing: Implications from London's Experiences. J. Geogr. Sci. 2011, 21, 49-64. [CrossRef]

97. Xie, C.; Huang, X.; Wang, L.; Fang, X.; Liao, W. Spatiotemporal Change Patterns of Urban Lakes in China's Major Cities between 1990 and 2015. Int. J. Digit. Earth 2018, 11, 1085-1102. [CrossRef]

98. Unhabitat. Urbanization and Development Emerging Futures World Cities Report 2016 Abridged Edition Key Findings and Messages. 2016. Available online: http://wcr.unhabitat.org/wp-content/uploads/2017/02/ WCR-2016_-Abridged-version-1.pdf (accessed on 22 March 2019).

99. Liu, Y.; Yang, Y.; Li, Y.; Li, J. Conversion from Rural Settlements and Arable Land under Rapid Urbanization in Beijing during 1985-2010. J. Rural Stud. 2017, 51, 141-150. [CrossRef]

100. He, X.; Qiao, Y.; Liu, Y.; Dendler, L.; Yin, C.; Martin, F. Environmental Impact Assessment of Organic and Conventional Tomato Production in Urban Greenhouses of Beijing City, China. J. Clean. Prod. 2016, 134, 251-258. [CrossRef]

101. Sun, C.; Sun, C.; Yang, Z.; Zhang, J.; Deng, Y. Urban Land Development for Industrial and Commercial Use: A Case Study of Beijing. Sustainability 2016, 8, 1323. [CrossRef]

102. Yu, M.; Liu, Y.; Dai, Y.; Yang, A. Impact of Urbanization on Boundary Layer Structure in Beijing. Clim. Chang. 2013. [CrossRef] 
103. CityPopulation. Pakistan: Provinces, Districts, Subdistricts, Cities, Towns-Population Statistics in Maps and Charts. 2017. Available online: http://www.citypopulation.de/Pakistan.html (accessed on 20 December 2018).

104. Angel, S.; Blei, A.M.; Civco, D.L.; Parent, J. Atlas of Urban Expansion; Choice Reviews Online Report; Lincoln Institute of Land Policy: Cambridge, MA, USA, 2012; p. 50-1227. [CrossRef]

105. Nations, U. World Urbanization Prospects; United Nations Report 2014. Available online: https://www.unilibrary.org/world-urbanization-prospects_527e5125-en.pdf (accessed on 27 March 2019).

106. Qureshi, S. The Fast Growing Megacity Karachi as a Frontier of Environmental Challenges: Urbanization and Contemporary Urbanism Issues. J. Goegr. Reg. Plan. 2010, 3, 306-321.

107. Kazmi. Quest of Urban Growth Monitoring from Myth to Reality. J. Basic Appl. Sci. 2013. [CrossRef]

108. Akhtar, S.; Dhahani, M.R. Urban Sprawl in Karachi. Sindh Univ. Res. J. 2013, 45, 482-491.

109. Asian Development Bank. Final Report: Karachi Mega Cities Preparation Project; Report 2005; Asian Development Bank: Mandaluyong, Philippines, 2005; p. 127. Available online: https://www.adb.org/ sites/default/files/project-document/69115/38405-pak-dpta.pdf (accessed on 6 April 2019).

110. Qureshi, S.; Breuste, J.H.; Lindley, S.J. Green Space Functionality along an Urban Gradient in Karachi, Pakistan: A Socio-Ecological Study. Hum. Ecol. 2010, 38, 283-294. [CrossRef]

111. Hasan, A. The Informal City. Choice Rev. Online 2013, 32, 3595. [CrossRef]

112. Liu, G.; Yang, Z.; Chen, B.; Ulgiati, S. Monitoring Trends of Urban Development and Environmental Impact of Beijing, 1999-2006. Sci. Total Environ. 2011, 409, 3295-3308. [CrossRef]

113. Qureshi, S.; Breuste, J.H.; Jim, C.Y. Differential Community and the Perception of Urban Green Spaces and Their Contents in the Megacity of Karachi, Pakistan. Urban Ecosyst. 2013, 16, 853-870. [CrossRef]

114. Mahboob, M.A.; Atif, I.; Iqbal, J. Remote Sensing and GIS Applications for Assessment of Urban Sprawl in Karachi, Pakistan. Sci. Technol. Dev. 2015, 34, 179-188. [CrossRef]

115. Assistant, M.H.; Manual, U. Healthy San Francisco. December 2007, Volume 3, pp. 439-441. Available online: https://healthysanfrancisco.org/ (accessed on 3 April 2019).

116. Anwar, N.H.; Mustafa, D.; Viqar, S.; Iqtidar, H. Violence in Millennial Karachi: A Scoping Study. Environ. Political Development Working Paper Series. No. 66. 2014. Available online: https://idl-bnc-idrc.dspacedirect. org/handle/10625/56739 (accessed on 12 April 2019).

117. Mapar, M.; Jafari, M.J.; Mansouri, N.; Arjmandi, R.; Azizinejad, R.; Ramos, T.B. Sustainability Indicators for Municipalities of Megacities: Integrating Health, Safety and Environmental Performance. Ecol. Ind. 2017, 83, 271-291. [CrossRef]

118. Dawodu, A.; Cheshmehzangi, A.; Akinwolemiwa, B. The Systematic Selection of Headline Sustainable Indicators for the Development of Future Neighbourhood Sustainability Assessment Tools for Africa. Sustain. Cities Soc. 2018, 41, 760-776. [CrossRef]

119. Phillis, Y.A.; Kouikoglou, V.S.; Verdugo, C. Urban Sustainability Assessment and Ranking of Cities. Comput. Environ. Urban Syst. 2017, 64, 254-265. [CrossRef]

120. Institute McKinsey Global. The China Urban Sustainability Index 2013. Report 2014, No. April. pp. 1-36. Available online: http://www.mckinseychina.com/wp-content/uploads/2014/04/china-urban-sustainabilityindex-2013.pdf (accessed on 16 January 2019).

121. Tan, Y.; Jiao, L.; Shuai, C.; Shen, L. A System Dynamics Model for Simulating Urban Sustainability Performance: A China Case Study. J. Clean. Prod. 2018, 199, 1107-1115. [CrossRef]

122. Wang, N.; Lee, J.C.K.; Zhang, J.; Chen, H.; Li, H. Evaluation of Urban Circular Economy Development: An Empirical Research of 40 Cities in China. J. Clean. Prod. 2018, 180, 876-887. [CrossRef]

123. Yi, H.; Güneralp, B.; Kreuter, U.P.; Güneralp, İ; Filippi, A.M. Spatial and Temporal Changes in Biodiversity and Ecosystem Services in the San Antonio River Basin, Texas, from 1984 to 2010. Sci. Total Environ. 2018, 619, 1259-1271. [CrossRef]

124. Han, H.; Sahito, N.; Van Thi Nguyen, T.; Hwang, J.; Asif, M. Exploring the Features of Sustainable Urban Form and the Factors That Provoke Shoppers towards Shopping Malls. Sustainability 2019, 11, 4798. [CrossRef]

(C) 2020 by the authors. Licensee MDPI, Basel, Switzerland. This article is an open access article distributed under the terms and conditions of the Creative Commons Attribution (CC BY) license (http://creativecommons.org/licenses/by/4.0/). 